NBER WORKING PAPER SERIES

THE IMPACT OF TUITION INCREASES ON UNDOCUMENTED COLLEGE STUDENTS' ATTAINMENT

Dylan Conger

Lesley J. Turner

Working Paper 21135

http://www.nber.org/papers/w21135

\author{
NATIONAL BUREAU OF ECONOMIC RESEARCH \\ 1050 Massachusetts Avenue \\ Cambridge, MA 02138 \\ April 2015
}

We are indebted to the City University of New York Office of Policy Research for making the data extracts available for analysis and Colin Chellman and Andrew Wallace in particular for providing key insights. We also thank Burt Barnow, Leah Brooks, Celeste Carruthers, Stephanie Riegg Cellini, Duncan Chaplin, Rajeev Darolia, Julia Gelatt, Jessica Howell, Jonathan Smith, Gema Zamarro, and participants at the meetings and seminars of the Association for Education Finance and Policy, Association for Public Policy Analysis and Management, American University, Brookings Institution, CUNY, Federal Reserve Bank of New York, Population Association of America, and Society for Research on Educational Effectiveness for very helpful comments. We are grateful for the excellent research assistance provided by Cinthia Josette Arevalo. The views expressed herein are those of the authors and do not necessarily reflect the views of the National Bureau of Economic Research.

NBER working papers are circulated for discussion and comment purposes. They have not been peerreviewed or been subject to the review by the NBER Board of Directors that accompanies official NBER publications.

(C) 2015 by Dylan Conger and Lesley J. Turner. All rights reserved. Short sections of text, not to exceed two paragraphs, may be quoted without explicit permission provided that full credit, including (C notice, is given to the source. 
The Impact of Tuition Increases on Undocumented College Students' Attainment Dylan Conger and Lesley J. Turner

NBER Working Paper No. 21135

April 2015

JEL No. H75,I21,J15

\begin{abstract}
We examine the impact of a temporary price shock on the attainment of undocumented college students enrolled in a large urban college system. In spring 2002, the City University of New York reversed its policy of charging in-state tuition to undocumented students. By fall 2002, the state legislature restored in-state rates. Using a differences-in-differences identification strategy, we estimate impacts on reenrollment, credits, grades, and degree completion. The price shock led to an immediate 8 percent decrease in senior college students' enrollment. Senior college students who entered college the semester prior to the price shock experienced lasting reductions in attainment, including a 22 percent decrease in degree receipt. Conversely, among senior college students who been enrolled for at least a year, the price shock only affected the timing of exit.
\end{abstract}

\title{
Dylan Conger
}

George Washington University

Trachtenberg School of Public Policy

and Public Administration

80521 st Street NW

Washington, DC 20052

dconger@gwu.edu

Lesley J. Turner

Department of Economics

University of Maryland

3115E Tydings Hall

College Park, MD 20742

and NBER

turner@econ.umd.edu 


\section{Introduction}

The share of high school graduates who enroll in college in the United States has grown substantially in recent decades, yet college completion rates have declined, especially among low-income students (Bound, Lovenheim and Turner, 2010, Bailey and Dynarski, 2011). A large body of research provides evidence that reducing the price of college can increase college attendance (e.g., Deming and Dynarski, 2010), yet far less is known about the effect of price on enrolled students' ultimate degree attainment. In this paper, we estimate the impact of an unanticipated and temporary tuition increase on the attainment of undocumented college students within a major urban university system. Focusing on undocumented students - the majority of whom are low-income and ineligible for federal and state financial aid - provides an opportunity to evaluate the effect of price changes on the attainment of enrolled students with limited financial resources.

Undocumented youth who migrate to the US as children are also a centerpiece of federal immigration reform proposals and recent higher education policies in many states. Although federal efforts to pass legislation extending legal status and other federal benefits to undocumented youth have been unsuccessful, 18 states now provide in-state tuition benefits to undocumented youth who received their secondary schooling in the state. This subsidy represents a substantial reduction in postsecondary costs given that out-of-state tuition rates are typically more than twice the in-state rates (Hemelt and Marcotte, 2011).

We estimate the effect of a temporary removal of this in-state subsidy on the outcomes of undocumented students enrolled in New York City's public university system, the City University of New York (CUNY). For a single semester, CUNY reversed its long-standing policy of charging in-state tuition rates to undocumented students from New York. Students enrolled in one of CUNY's "senior" colleges (institutions that offer both bachelor's and associate's degrees) experienced a 123 percent price increase, while associate's degree-seeking community college students experienced a 23 percent increase 1 This one-semester price shock provides a natural experiment for examining the effect of tuition on undocumented students' attainment, measured by their reenrollment, credit accumulation, grades, and degree receipt.

To identify impacts on short-run attainment, we use a generalized differences-in-differences identification strategy that compares changes in undocumented students' outcomes before and after the tuition hike to differences in the outcomes of documented noncitizens (93 percent of whom are permanent residents), a group unaffected by the policy change. The elimination of the in-state tuition subsidy substantially decreased undocumented senior college students' short-run attainment, with reenrollment falling by 8 percent in the

\footnotetext{
${ }^{1}$ Though postsecondary institutions are typically classified as "four-year" or "two-year", we use the CUNY System's label of "senior" college (as opposed to "four-year" college) because approximately 40 percent of CUNY's senior college students start out in an associate's degree program and these students face the same tuition charges as senior college students enrolled in a bachelor's degree program. Thus, the magnitude of the price change is specific to the institution, not the degree. We elaborate on this point in Section 2
} 
semester of the price increase. Among undocumented community college students, the price increase had no effect on reenrollment, but decreased credits earned by approximately 8 percent. We can rule out all but very small impacts on grades for both senior and community college students, and provide evidence that senior college students induced to leave school by the price shock were not negatively selected, on average.

We estimate that over half of the senior college students induced to dropout by the spring 2002 price shock would not have successfully maintained enrollment in the following semesters, even in the absence of any price increase. For these inframarginal students, the price shock affected the timing of college exit but not long-run attainment. Inframarginal exits occur primarily among students who spent at least one year in college before the price increase. Conversely, senior college students who enrolled in fall 2001 - the semester immediately prior to the tuition increase - experienced lasting reductions in attainment. One interpretation of this finding is that as college students gain more experience, they are better able to predict their long-run success. As a result, price shocks close to college entry are more likely to affect marginal students who would have ultimately been successful to dropout.

To evaluate the long-run impacts of the price shock, we compare the outcomes of undocumented students in the the 2000 and 2001 entry cohorts to those of undocumented students who started college in 1999, again using differences in documented noncitizens' outcomes by entry cohort to generate a counterfactual. We estimate that the price shock experienced by undocumented senior college students from the 2001 entry cohort resulted in a 22 percent decrease in degree receipt within eight years of entry. We find no evidence of long-run impacts on community college students' outcomes.

Our paper contributes to research and policy concerning the effect of college prices on human capital acquisition. Research reviewed by Deming and Dynarski (2010) points to significant increases in collegegoing among students who experience an exogenous drop in price due to policy changes. However, there is less evidence on the impact of price changes on the postsecondary attainment of students after they have already spent time in college. Although gaps in college entry by family income have shrunk in recent years, low-income students' graduation rates remain low (Bailey and Dynarski, 2011), suggesting that the effects of financial need on attainment persist beyond the enrollment margin. A handful of studies suggest that increases in need-based grants can boost the attainment of enrolled students when such increases are not offset by reductions in other aid $\mathrm{L}^{2}$ Bettinger (2004) provides evidence that Pell Grant aid increases Ohio public college students' persistence rates between the first to the second year of college ${ }^{3}$ Similarly GoldrickRab et al. (2012) find higher first- to second-year persistence rates among Pell Grant recipients in Wisconsin

\footnotetext{
${ }^{2} \mathrm{~A}$ related topic is the role of credit constraints in students' postsecondary decisions. In a setting where students faced no direct tuition charges, Stinebrickner and Stinebrickner 2008) find that most dropouts do not face credit constraints, suggesting a potentially large role for non-financial factors in students' persistence decisions.

${ }^{3}$ Estimates suggest that an additional $\$ 1,000$ in Pell Grant aid increases reenrollment by 3 to 4 percentage points, although these estimates are not robust to controlling for institution fixed-effects.
} 
colleges who were randomly-selected to receive an additional $\$ 1,000$ in aid. Illustrating the importance of accounting for loan crowd-out, Marx and Turner (2015) estimate that Pell Grant aid does not increase persistence or attainment in a setting where additional grant aid reduces aid from federal loans. Castleman and Long (2013) estimate the impact of state need-based grant aid on Florida high school graduates' college enrollment and attainment and impacts on both initial enrollment and degree receipt. However, the positive effect of grant eligibility on enrollment makes it is difficult to determine whether grant aid eligibility increased attainment above and beyond its impacts on college attendance. Addressing concerns of both selection into college and crowd-out of federal and institutional grant aid, Angrist et al. (2014) examine the impact of a need- and merit-based scholarship in Nebraska. They find substantial impacts on the persistence of nonwhite students, but estimate that overall, at least 80 percent of funds were spent on students whose behavior was not affected by the grant 4

We contribute to research on the effect of prices on enrolled students' attainment in several ways. First, we estimate both short- and long-run impacts of a price shock, focusing on semester to semester reenrollment as well as degree receipt. Second, our context allows us to isolate the impact of price increases on student outcomes because undocumented students are unable to easily offset the price shock with additional grant aid or borrowing. Finally, to our knowledge, ours is the first study that provides suggestive evidence that students early in their college careers are more vulnerable to price increases than more experienced students.

Our findings also contribute to research examining the effect of state, local, and institutional policies aimed at making college more accessible to undocumented students. Four prior studies use national survey data and a standard difference-in-difference framework to estimate the effects of in-state tuition subsidies on undocumented students' college enrollment decisions. Kaushal (2008), Chin and Juhn (2011), and Darolia and Potochnick (2014) estimate the average effects of in-state tuition across all states with such policies, while Flores (2010) focuses on the impact of Texas' in-state tuition subsidy. All four studies rely on data from the Current Population Survey (CPS) or the American Community Survey (ACS) and proxy for undocumented status with Mexican (or Hispanic) students who are not citizens. Three of the four studies find positive impacts of eligibility for the in-state tuition subsidy on college enrollment of 2 to 6 percentage-

\footnotetext{
${ }^{4} \mathrm{~A}$ related body of research explores the role of monetary incentives tied to other supports (such as mentors) or requirements (such as a minimum course load or grade point average) on enrolled students' effort and degree completion. Dynarski (2008) estimates positive impacts of state merit-based aid on persistence and graduation with larger effects among female students. Scott-Clayton (2011) studies West Virginia's PROMISE scholarship and finds positive impacts only during years in which aid was tied to performance. Results from the Student Achievement and Retention Project, an experimental study that randomly-assigned students in a Canadian university to receive financial aid (tied to grades), support services, or both, suggests higher levels of merit aid coupled with support services increased female (but not male) students' grade point average and persistence (Angrist, Lang and Oreopoulos 2009). However, a follow-up study that involved stronger incentives found smaller impacts on attainment (Angrist, Oreopoulos and Williams, forthcoming). Finally, a series of papers examine the impact of randomly assigned student incentives and find evidence of small, but significant impacts on attainment (e.g., Patel and Rudd, 2012 Barrow et al. forthcoming). Although most studies examining student incentives in higher education find positive impacts on enrolled students' attainment, assistance is based on performance and often involves both monetary and additional supports. Our study focuses exclusively on the estimation of tuition price effects.
} 
points (Kaushal, 2008, Flores, 2010, Darolia and Potochnick, 2014). Our study builds on this prior work by estimating the effect of these subsidies on students' retention and ultimate degree receipt. In addition to informing sub-national policies, evaluations of price effects on both college-going and degree attainment inform federal immigration reform proposals aimed at providing undocumented youth with a pathway to citizenship through college attendance and completion.

The remainder of this paper proceeds as follows: in Section 2, we describe the CUNY System and provide background information on undocumented young adults. We discuss our data and sample in Section 3 and describe our empirical approach in Section 4. In Section 5, we present estimates of the impact of the price increase on undocumented students' attainment during the semester of the policy change and in the immediately following semesters. Section 6 presents our estimates of the impact of the tuition increase on longer-run outcomes, including degree receipt, while Section 7 concludes.

\section{The CUNY System and Undocumented Students}

As an established immigrant gateway, New York is home to approximately three million foreign-born residents, an estimated 625,000 of whom are undocumented (American Community Survey, 2010; Passel and Cohn, 2010). In fall 2013, approximately 8,300 undocumented students were enrolled in New York state colleges, with 80 percent residing in New York City and attending one of the CUNY System schools (DiNapoli) and Bleiwas, 2014) 5

In the period we examine, the CUNY System included 11 senior colleges and 6 community colleges. We label CUNY schools as senior or community colleges instead of using the standard labels of two- or fouryear institutions because four of the 11 senior CUNY colleges offer both associate's and bachelor's degree programs ${ }^{6}$ In addition, CUNY senior college students who are enrolled in an associate's degree program face the same tuition rates as those in a bachelor's degree program. In 2001, nominal in-state tuition for a full-time student was $\$ 3,200$ per year at senior colleges and $\$ 2,500$ per year at community colleges. Nominal out-of-state rates faced by full-time senior and community college students were $\$ 6,800$ and $\$ 3,076$, respectively.

Our identification strategy relies on unanticipated shocks to undocumented students' eligibility for in-state rates. In 1989, long before any state considered granting in-state tuition to undocumented students, New York City Mayor Edward Koch issued an executive order that extended in-state prices to CUNY students

\footnotetext{
${ }^{5}$ An additional 18 percent of undocumented students were enrolled in a SUNY institution in one of the five counties surrounding New York City, and the remaining 2 percent attended a SUNY institution elsewhere in the state.

${ }^{6}$ This practice is not unique to the CUNY System. According to data from the Integrated Postsecondary Education Data System (IPEDS), in 2013, 60 percent of public institutions categorized as "four-year" schools also offered certificate or associate's degree programs.
} 
who lacked documentation but who could demonstrate that they graduated from a New York high school or received a GED from the state (Rincón, 2008). Yet in the fall of 2001, shortly after the terrorist attacks of September 11, the CUNY Chancellor overturned this policy and announced that starting in the spring 2002 semester, CUNY would charge undocumented students who had previously qualified for the in-state subsidy out-of-state tuition rates 7 Although no changes to the new pricing policy were anticipated at the beginning of the semester, by April 2002, Governor George Pataki announced his support for legislation offering in-state tuition to undocumented students with ties to New York State 8 In the summer of 2002, the state legislature passed a law that restored in-state tuition benefits for eligible undocumented students. Thus, for the spring 2002 semester only, tuition rates for undocumented students at senior colleges more than doubled (from $\$ 133$ to $\$ 283$ per credit). With a full-course load of 12 credits, this represented a price increase of $\$ 1,800$ for the semester. The price increase faced by undocumented community college students was smaller (from $\$ 104$ to $\$ 128$ per credit), with full-time students facing an approximately $\$ 300$ (23 percent) increase for the semester.

\subsection{Characteristics and outcomes of undocumented students}

The Pew Hispanic Center estimates that there are approximately 1.7 million undocumented immigrants under the age of 31 who migrated to the US at before they were 16 (Passel and Lopez, 2012). The proposed Development, Relief, and Education for Alien Minors (DREAM) Act would provide eligible youth with a pathway to permanent residency status and access to federal benefits, such as aid for college 99 Congress voted against the DREAM Act in 2001, 2007 and 2010. In an effort to jump-start reforms targeting undocumented youth, in 2012, the Obama administration announced the Deferred Action for Childhood Arrivals (DACA) program - an executive order that shields eligible undocumented immigrants from deportation and provides them with temporary work authorization. President Obama attempted to expand the DACA program to other undocumented residents in November 2014; however, a federal court order has suspended that action. In the meantime, several states, Boards of Regents, and individual institutions have opted to extend in-state tuition benefits to undocumented college students enrolled in public institutions. As of 2014, most of the top immigrant-receiving states (including California, New York, Texas, Florida, New Jersey, and Illinois) have granted the subsidy to eligible undocumented youth.

\footnotetext{
${ }^{7}$ See, for instance, Karen W. Arenson's 2001 New York Times article, "CUNY raises tuition rates for foreigners here illegally." Downloaded on 2/2/2014 from http://www.nytimes.com/2001/11/03/nyregion/cuny-raises-tuition-rates-for-foreignershere-illegally.html

'See Joyce Purnick's New York Times article, "Metro Matters; Tuition, Out of State And Beyond," (downloaded 1/5/2015 from http://www.nytimes.com/2002/02/18/nyregion/metro-matters-tuition-out-of-state-and-beyond.html) and Sara Hebel's May 2002 Chronicle of Higher Education article, "N.Y. Governor Backs Plan to Help Some Illegal Immigrants."

${ }^{9}$ In addition to removing the threat of deportation and the opportunity for legal employment, the bill encourages college enrollment by offering a pathway to legalization for students who obtain a college degree.
} 
Despite the ample policy attention given to undocumented college students, there are few large-scale analyses of their outcomes because federally-sponsored surveys and other administrative data sources are prohibited from asking respondents to state their immigration status. Several qualitative studies of undocumented college students identified through non-probabilistic sampling methods find that students who lack documentation face substantial barriers to college success $($ Abrego, 2006, Contreras, 2009, Perez, 2009, Gonzales, 2011; Muñoz and Maldonado, 2012). Most undocumented students come from families with limited financial resources and parents who are themselves undocumented and unable to provide guidance and support in navigating US institutions. Thus, undocumented students face many of the same hurdles encountered by other low-income, first generation, college students. Their lack of documentation poses greater challenges to normal college pursuits, such as obtaining driver's licenses, places to live, student identification cards, and employment both on and off campus (Contreras, 2009, Muñoz and Maldonado, 2012).

At the same time, these studies suggest that undocumented youth demonstrate a high level of ambition and resilience. Consistent with this anecdotal evidence, Conger and Chellman (2013) show that undocumented CUNY students' academic outcomes resemble those of other noncitizen immigrant groups (namely permanent residents and visa holders), all of whom earn higher GPAs and complete more credits than US citizens. These findings are in line with research on immigrant students in the K-12 education system, which often finds that they are a positively-selected group who outperform native-born students with observablysimilar race and class profiles (e.g., Kao and Tienda, 1995, Schwartz and Stiefel, 2006).

In short, many undocumented college students appear to fall in the category of high-ability, low-income students. As low-income students, they should be highly responsive to tuition shocks. Furthermore, they are ineligible for most other sources of financial aid and are less able to compensate for tuition increases with anything other than employment in the informal labor market or loans from family members or other informal sources. Following the news that tuition will increase in the next semester, we predict that some undocumented students will exit college, reduce their credit-load, and/or devote less time to their school work. These negative impacts may continue in later semesters even when the in-state rates are restored if students face costs associated with switching between working and attending college or expect to face other tuition increases in the future 10

\footnotetext{
${ }^{10}$ While some students can also choose to lower their consumption, two-thirds of students enrolled in the CUNY System already live with their parents or guardians making reductions in housing consumption less of an option for lowering the cost of attendance. See CUNY's "2012 Student Experience Survey," available at: http://cuny.edu/about/administration/offices/ira/ir/surveys/student/SES2012FinalReport.pdf for further details (accessed 23 September 2014).
} 


\section{Data and Sample}

Our analyses rely on administrative data from the CUNY System, which includes information on first-time, degree-seeking students' demographic characteristics and academic outcomes. Crucially, CUNY records students' citizenship and immigration status for the purpose of tuition determination. Upon enrollment, students are asked to identify themselves as US citizens, permanent residents, student or temporary visa holders, asylees or refugees, or undocumented ${ }^{11}$ Students must submit documentation to validate their selfreported status and those who either report that they are undocumented or who fail to provide documentation (e.g., current visa, temporary authorizations to live and work in the US) are recorded as undocumented. To qualify for in-state tuition, undocumented students are required to submit a notarized affidavit stating that they plan to legalize their status as soon as they are eligible. These students also must demonstrate that they received their secondary schooling in New York State, either from a New York high school or GED program.

Our main sample consists of the 17,915 noncitizen students who obtained a high school diploma or GED from New York State and entered an associate's or bachelor's degree program between fall 1999 and fall $2001{ }^{12}$ The characteristics of these students and the 43,159 citizens who earned a high school degree or GED from New York State and entered college between fall 1999 and fall 2001 are displayed in the first three columns of Table 1 . Of the 61,074 students in these entry cohorts, 29 percent are noncitizens and approximately 3 percent are undocumented.

Compared to noncitizens, CUNY students with US citizenship are younger, more likely to be Hispanic or White and less likely to be Asian. Citizens are also more likely to be classified as disabled at college entry and less likely to have graduated from a New York City high school or be GED recipients. Although citizens enter CUNY with lower high school achievement, as measured by the CUNY college admissions average (a standardized measure of high school GPA ranging from 0 to 100), they are less likely to require remedial classes compared to noncitizens. Finally, citizens are more likely to enter college in a bachelor's

\footnotetext{
${ }^{11}$ A US citizen is an individual who either was born in the US or obtained citizenship through the process of naturalization. Permanent residents (also known as a green card holders) are defined by the US Citizenship and Immigration Services as "any person not a citizen of the United States who is residing the in the U.S. under legally recognized and lawfully recorded permanent residence as an immigrant" (see the U.S. Citizenship and Immigration Services Glossary, available at: http://www.uscis.gov/tools/glossary). Visa holders are individuals who reside in the U.S. temporarily for a specific purpose, typically to work or attend school. Finally, an undocumented immigrant is one who does not have legal authority to live or work in the US. This status is achieved either by entering the country illegally, or by violating the terms of a legal visa. US citizens and permanent residents are eligible for all forms of aid and loans from governmental and private sources. Most visa holders are ineligible for these sources of aid, with the one exception being Cuban and Haitian entrants.

${ }^{12}$ Among the 83,041 degree-seeking students in these entry cohorts, we drop 5,033 (6 percent) with missing citizenship or documentation information and an additional 455 (less than 1 percent) missing age at entry. Additionally, restricting our sample to students who earned their high school diploma or GED in New York State excludes 375 (17 percent) undocumented students and 8,553 (35 percent) documented noncitizens. We impose this restriction to ensure that undocumented students in our sample were eligible for in-state tuition prior to Fall 2001 and to increase the comparability of documented and undocumented noncitizens. Among citizens, 7,555 (15 percent) are excluded due to this restriction.
} 
degree program and are less likely to initially enroll in a nonselective institution 13

Documented and undocumented noncitizens also differ by their racial/ethnic backgrounds; undocumented students are more likely to be Black and less likely to be White or Asian than their documented classmates. Undocumented students are the least likely of the three groups to pursue a bachelor's degree at entry, and enter less selective CUNY institutions than documented noncitizens. Finally, undocumented students are more likely to be GED recipients and less likely to be graduates of New York City high schools compared to documented noncitizen students.

The final three columns of Table 1 display $p$-values from tests of the equality of the characteristics of citizen versus noncitizen students, undocumented versus documented noncitizens, and all three groups, respectively. Although many of the differences in characteristics across groups are statistically significant, by in large, these differences are small in magnitude, especially when comparing documented and undocumented noncitizens. Appendix Tables A.1 and A.2 display the characteristics of senior and community college students, respectively; after conditioning on college type, we find even fewer significant differences in the characteristics of documented and undocumented noncitizen students.

Table 1 also highlights one of the unique features of our study location. New York City is the largest city in the US and contains a diverse student population (of both natives and immigrants). Undocumented youth living in New York City come from all over the world, not just from Latin and South America as is common in other regions. Thus, the responses of CUNY undocumented students to tuition shocks may not resemble the responses of other undocumented students across the nation. We address concerns over the generalizability of our estimates in Section 5.4 by examining whether the impact of the tuition increase varies by race/ethnicity.

\section{Empirical Framework}

Our data and setting provide several advantages for estimating effects of price shocks on undocumented students' outcomes. First, the decision to eliminate the in-state tuition subsidy for undocumented students appears to have been made in reaction to $9 / 11$ and not to any patterns observed among undocumented or documented noncitizens before fall 2001 (Rincón, 2008). Thus, there is no reason to expect undocumented students were experiencing changes in any relevant drivers of attainment, such as financial need, courses, institutions, or grades, relative to their documented counterparts who were not exposed to the price shock.

\footnotetext{
${ }^{13}$ We classify institutions' selectivity using the Barron's Guide, which places the following colleges in each rank: "Very Competitive" includes Baruch; "Competitive" includes Brooklyn, City, Hunter, John Jay, and Queens; Less "Competitive" includes Lehman; "Noncompetitive" includes City Tech, Medgar Evers, New York City College of Technology, Staten Island, and York; "Nonselective" includes Borough of Manhattan Community College and Bronx, Hostos, Kingsborough, LaGuardia, and Queensborough Community Colleges.
} 
Second, undocumented students are ineligible for most federal, state, and private grants and loans, making it difficult for these students to buffer the tuition hike with increased financial support from other sources ${ }^{14}$ In addition, no exceptions to the elimination of the in-state tuition subsidy appear to have been granted, or additional supports made available, rendering all previously-eligible undocumented students subject to the same price increase. These unique circumstances means that our estimates will more closely measure the theoretical effects of price shocks on postsecondary attainment than studies that examine the effect of a specific subsidy (e.g., Pell Grant aid) on the outcomes of students who have access to other potentially offsetting resources (e.g., federal loans). Third, most surveys do not request that respondents state their immigration status or provide documentation to validate their responses. Thus, studies that rely federal data sources, such as the ACS or the CPS, code both undocumented students and other noncitizen immigrants (namely, permanent residents and those with legal visas) as treatment group members, leading to measurement error in students' exposure to changes in tuition. Our unique data set allows us to more accurately identify the undocumented, thereby reducing measurement error and allowing us to difference out non-price impacts on attainment by using documented noncitizens as the control group 15

To estimate the effects of the price shock, we focus on the three semesters surrounding the policy change and the semester of the price shock: fall 2000 through fall 2004 (with spring 2002 at the center of the series) ${ }^{16}$ We estimate generalized differences-in-differences models, where we allow the impact of the policy change on attainment to have persistent effects after in-state rates were restored to undocumented students:

$$
Y_{i s c t}=\beta_{1} \text { Treat }_{t} \times \text { Undoc }_{i}+\beta_{2} \text { Post }_{t} \times U n d o c_{i}+\gamma \mathbf{X}_{\mathbf{i}}+\delta_{s c}+\delta_{t}+\tau \times \delta_{c}+\epsilon_{\text {isct }}
$$

In equation (1), $Y_{\text {isct }}$ is one of several attainment outcomes in semester $t$ for student $i$ who initially entered college $s$ as a member of cohort $c$. Undoc $i$ is set to one if the student is undocumented and $\mathbf{X}_{\mathbf{i}}$ is a vector of student covariates measured in the first semester of college including indicators for documentation status (permanent resident, student visa holder, or asylee/refugee), initial degree program (associate's versus bachelor's degree), high school GPA, high school type (NYC public, NYC private, GED, or other New York state school), need for remedial courses, disability, age, gender, race/ethnicity (Black, Hispanic, White, or other), and single parent status. We include semester and college by cohort fixed effects, $\delta_{t}$ and $\delta_{s c}$, respectively, and cohort-specific linear trends $\tau \times \delta_{c}$, where $\tau=t-c$ represents semesters since entry. Finally, under the identifying assumption that the outcomes of undocumented and documented noncitizen

\footnotetext{
${ }^{14}$ Undocumented students are ineligible for all federal sources of aid and loans, including the Pell and Stafford programs. They are also ineligible for the New York Tuition Assistance Program (TAP), the New York State funded grant to low-income students of up to $\$ 5,000$.

${ }^{15}$ For instance, we can account for the removal of the subsidy leading noncitizens to feel unwelcome in the CUNY System. In other settings, such "chilling effects" have been shown to alter documented noncitizens' behavior (e.g., Watson, 2014).

${ }^{16}$ In Section 5.2 , we show that our results are robust to larger and smaller windows.
} 
students would have followed similar trends in the absence of the price increase, $\epsilon_{i s c t}$ represents a random error component. We estimate separate models for students enrolled in senior and community colleges. Student-semester observations are dropped following degree receipt 17 Standard errors are clustered at the cohort by college level.

The coefficient on the interaction between the indicator for the semester of the price increase $\left(\right.$ Treat $\left._{t}\right)$ and undocumented status, $\beta_{1}$, represents the change in attainment during the semester of the tuition hike on the outcomes of undocumented students relative to documented noncitizens. Additionally, $\beta_{2}$ represents the change in outcomes for undocumented students in the semesters after the tuition hike (compared to the semesters before the increase) relative to the same change for documented noncitizens 18

The main identifying assumption underlying our research design is that, in the absence of the tuition increase, the outcomes of documented noncitizen and undocumented students in the spring 2002 and the following semesters would have followed similar trends. A possible violation of this assumption would be underlying trends in the outcome variables that are correlated with the policy change. Examination of the pre-policy trends in attainment, discussed in the following section, suggests that prior to the policy change, outcomes of documented and undocumented noncitizens followed similar paths.

In this case, an additional potential violation comes from the terrorist attacks of September $11,2001$. These attacks had a major impact on New York City residents and institutions and may have uniquely influenced the schooling choices of immigrant students. If the undocumented students felt disproportionately impacted, perhaps reducing their schooling investments due to a decrease in morale or increased fear of deportation, then observed changes in spring 2002 could be due to the terrorist attack and not to the change in the tuition policy. Though we are unable to directly examine the academic response to $9 / 11$, we can test whether the policy change led to reductions in attainment among documented noncitizens relative to US citizens. Documented noncitizens at CUNY were not subject to the new tuition policy, but they were exposed to the post 9/11 environment and may have felt a similar level of hostility and reduction in attachment to US institutions. As discussed in the following section, trends before and after $9 / 11$ reveal no evidence that documented noncitizens' enrollment or attainment differed from that of US citizens.

\section{The Impact of Tuition Increase on Attainment}

To illustrate our identification strategy and preview our main results, we plot average average reenrollment (Figure 1), credits attempted (Figure 2), and credits earned (Figure 3) of citizens, documented noncitizens,

\footnotetext{
${ }^{17}$ Only 2 percent of student by semester observations are dropped due to this restriction.

${ }^{18}$ Main effects for Treat $t$ and Post $t$ are subsumed by the vector of semester fixed effects while the main effect for $U n d o c_{i}$ is included in $\mathbf{X}_{\mathbf{i}}$.
} 
and undocumented students over the seven semesters surrounding the policy change 19 In each figure, the solid black line represents the average outcomes of undocumented students, the dashed dark gray line represents the average outcomes of documented noncitizens, and the solid light gray line represents the average outcomes of citizens. Differences between the black and dashed gray lines before and after the policy change will approximate our differences-in-differences estimates. In each figure, the sample in Panel A is limited to students who initially enrolled in a CUNY senior college between fall 1999 and fall 2001, while Panel B is limited to community college students.

Prior to spring 2002, both documented and undocumented noncitizens who initially entered a senior college were more likely to reenroll relative to citizens (Figure 1. Panel A). The decline in mean reenrollment for all groups reflects decreases in persistence over time. Reenrollment rates for documented noncitizen and undocumented senior college students are quite similar prior to spring 2002, while in spring of 2002, when undocumented students' tuition rates doubled, their reenrollment drops substantially. Following spring 2002, reenrollment continues to monotonically decline for all three groups. Relative to documented noncitizens and citizens, decreases in undocumented students' reenrollment slow slightly after in-state tuition rates were restored. Trends in community college students' reenrollment - shown in Panel B - suggest that the price shock did not alter undocumented community college students' reenrollment relative to their documented or citizen peers.

Figures 2 and 3 display trends in credits attempted and credits earned, respectively. Since we do not condition on enrollment, changes in credits attempted and earned will represent a combination of intensive (e.g., course load reductions or less effort devoted to courses) and extensive margin (e.g., dropout) responses. Documented and undocumented noncitizens attempt and earn more credits than citizens. Among senior college students, trends in credits attempted and earned are similar for documented and undocumented noncitizens before spring 2002. In the semester of the price increase, undocumented senior college students' attempt and earn fewer credits relative to documented noncitizens, suggesting that the policy change reduced both credits attempted and earned. Following spring 2002, undocumented senior college students' credit accumulation rebounds slightly, but remains lower than in the pre-spring 2002 semesters. Among undocumented community college students, pre-spring 2002 trends in credit accumulation do not track documented noncitizens' trends as well as in the case of senior college students. Additionally, there is little evidence of significant decreases in credits attempted or earned by undocumented community college students relative to their documented peers except in the spring 2002 semester.

The pre- and post-policy trends of US citizens and documented noncitizens reveal no substantial differ-

\footnotetext{
${ }^{19}$ Note that we use the term "reenrollment" as opposed to "enrollment" as the latter is typically used to refer to the decision to pursue a degree. We also do not use the term "persistence" because we focus here on reenrollment that is not conditional on the previous semester (later, we examine persistence rates where reenrollment in time $t$ is conditional on enrollment in $t-1$ ).
} 
ences between these two groups in any of the figures. The absence of a difference indicates that documented noncitizens appear not to have reacted to the tuition hike (via a chilling effect) or to the terrorist attacks of 9/11. Although the absence of a reaction to $9 / 11$ among documented noncitizens (relative to citizens) does not entirely rule out 9/11 as an explanation for undocumented students' attainment decreases, it suggests that $9 / 11$ is unlikely to be the major cause of the changes we observe.

\subsection{Impacts on reenrollment, credits attempted, and credits earned}

Table 2 reports the coefficients and standard errors on the interaction of undocumented status and indicators for the semester of the price increase (spring 2002) and semesters following the price increase (post-spring 2002) from estimation of Equation (1). We examine impacts on reenrollment (Panel A), credits attempted (Panel B), and credits earned (Panel C). We test the equality of the estimated parameters on the interaction of undocumented and spring 2002 and the interaction of undocumented and post-spring 2002, which provides a test of whether the initial impacts of the price increase led to persistent reductions in undocumented students' attainment even after in-state prices were restored.

The price shock led to a 7 percentage point decrease in undocumented senior college students' reenrollment, an 8 percent decline relative to fall 2001 reenrollment rates. The price shock resulted in smaller, but significant impacts on senior college students' reenrollment in the semesters after the tuition hike was reversed, leading to a 3 percentage point (3 percent) decrease. The difference between the immediate and medium-run impacts of the tuition hike on senior college students' reenrollment suggests that either students induced to leave college in spring 2002 by the price shock returned to school after in-state tuition rates were restored or that approximately half of the students who initially dropped out in response to the price shock would have left in the following semesters even in the absence of the policy change. We distinguish between these explanations by examining whether the the probability of returning to a CUNY institution, conditional on having dropped-out, increased among undocumented students in the post-spring 2002 semesters. We find no evidence that undocumented senior college students who left CUNY in spring 2002 or earlier were more likely return to college once in-state tuition rates were restored 20

Among undocumented community college students, we find small and insignificant impacts of the price increase on reenrollment in spring 2002 and later semesters ${ }^{21}$ Our estimates imply a price elasticity of enrollment equal to -0.06 for senior college students and -0.08 for community college students. Thus, even though the estimated impact of the price shock on community college students' reenrollment is substantially smaller

\footnotetext{
${ }^{20}$ Our point estimates, although insignificant, suggest that undocumented senior college students were 3.4 percentage points (14 percent) less likely to return to a CUNY institution after spring 2002 (full results available upon request).

${ }^{21}$ We can reject the equality of the estimated impact of the price increase in spring 2002 for community versus senior college students $(p=0.005)$, but the difference in the estimated impact of the price change after spring 2002 is not statistically significant $(p=0.291)$.
} 
than that of senior college students, because the price increase undocumented community college students were exposed to was also small, our estimates imply a slightly larger (albeit not statistically distinguishable from zero) price elasticity.

Undocumented students from both senior and community colleges attempted and earned fewer credits in spring 2002 (Table 2, Panels B and C) ${ }^{22}$ Again, we do not condition on enrollment when estimating impacts on credits attempted and earned, therefore, our point estimates represent the combined impact of the price increase on intensive and extensive margin responses. Undocumented senior college students attempted 0.9 fewer credits in spring 2002 (a 10 percent decrease relative to fall 2001) and earned 0.8 (9 percent) fewer credits. Undocumented community college students attempted and earned 0.4 fewer credits in spring 2002, representing 7 and 8 percent declines from baseline attainment, respectively. Both community and senior college students continued to earn fewer credits even after in-state tuition rates were restored 23 The similarities between impacts on credits attempted and earned, as well as the trends shown in Figures 2 and 3 , suggest that observed decreases in credit accumulation are largely driven by decreases in credits attempted, rather than declines in course pass rates. Thus, we focus on estimating impacts on credits earned in the remaining analyses. Estimated impacts on credits attempted quite similar (available upon request) ${ }^{24}$

In Figures 4 and 5 , we display point estimates and corresponding 95 percent confidence intervals from a modified version of equation (11), where Treat ${ }_{t} \times U n d o c_{i}$ and Post $_{t} \times U n d o c_{i}$ are replaced with interactions between $U n d o c_{i}$ and a set of indicators for semesters before and after the price increase. Fall 2001 (the semester immediately prior to the price shock) serves as the omitted category. These event study models serve two purposes. First, we can test for differences in the trends in documented and undocumented students' outcomes prior to the price shock. Second, we can test how the impact of the price shock changes in each semester after spring 2002.

Differences in reenrollment rates between documented and undocumented senior college students are not statistically significant before the price shock (Figure 4. Panel A). However, undocumented senior college students are more than 5 percentage points less likely to reenroll in spring 2002 and around 3 percentage points less likely to reenroll in fall 2002. After fall 2002, impacts on undocumented senior college students' reenrollment remain negative but are no longer statistically significant at the 5 percent level. Conversely, we find no evidence of statistically significant decreases in enrollment of undocumented community college students

\footnotetext{
${ }^{22}$ We can reject the equality of the estimated impact of the price shock on credits attempted by senior versus community college students in spring 2002 with $p=0.032$. Differences in estimated impacts on credits earned in spring 2002 are not statistically significant $(p=0.103)$.

${ }^{23}$ Impacts on credits attempted and earned in the semesters after spring 2002 are not statistically distinguishable between senior and community college students ( $p=0.400$ and $p=0.520$ for credits attempted and earned, respectively).

${ }^{24}$ We also investigate whether the impact of the price increase on senior college students differed by students initial degree program, since some senior colleges contain both bachelor's and associate's degree seeking students. As shown in Appendix Table A.3, none of the differences in the estimated impact of the price increase by degree program are statistically significant.
} 
in spring 2002 or later semesters relative to their documented peers (Panel B). Differences in reenrollment three semesters prior to the price shock are statistically significant, suggesting that among community college students, trends in documented noncitizens' outcomes may not provide as good a counterfactual for undocumented students as in the case of senior college students.

Trends in credits earned for documented and undocumented senior college students prior to the price shock are also not statistically distinguishable (Figure 5, Panel A). Although the drop in credits earned by undocumented senior college students relative to their documented counterparts is largest in spring 2002, statistically significant differences in credit accumulation persist for at least two semesters following the restoration of in-state rates. Among undocumented community college students, only the spring 2002 difference in credit accumulation is statistically significant at the 95 percent level (Panel B).

\section{$5.2 \quad$ Robustness tests}

Tables 3 and 4 display estimated impacts on reenrollment and credits earned from additional robustness tests. Column 1 includes estimates from models that include student fixed effects. Column 2 contains estimates from models that use a larger window around the policy change (4 semesters) and column 3 contains estimates from models that use a smaller window (2 semesters).

Including student fixed effects will account for student-specific time-invariant characteristics. To the extent that students' time-invariant unobservable characteristics are correlated with both their attainment and exposure to the policy change, our main estimates will suffer from omitted variables bias. Conversely, our fixed effects models use students' own pre-treatment outcomes as their counterfactual outcome in the absence of the policy change. In this case, documented noncitizens only allow us to identify cohort by school and semester fixed effects, since these students experience no change in their exposure to the tuition increase. The disadvantage of using student fixed effects is that attenuation bias due to classical measurement error in the "treatment" variables will be exacerbated, biasing our estimates towards zero. Even if documentation status contains minimal measurement error, our "treatment" variable will contain measurement error by construction. This is because not all students are still enrolled in spring 2002, but we treat all students as being affected by the price increase. The second and third robustness tests vary the size of the window around the policy change that we use to define our sample, to show that our results are not driven by the three semester window we use in our main specification.

We estimate similar impacts of the price increase on undocumented students' reenrollment using these alternative models (Table 3). Including a larger or smaller window of semesters around the price increase results in estimates that are quite similar to our main results. Impacts on undocumented community college 
students' reenrollment are insignificant in every specification. The estimated impacts of the policy change on credits earned are also robust to these alternative specifications (Table 44. Among senior college students, the estimates suggest that the price increase led to an 8 to 9 percent decrease in credits earned in spring 2002, and a 5 to 6 percent decrease after the in-state subsidy was restored. Among community college students, estimates suggest that the price increase resulted in an 5 to 8 percent decrease in credits earned in spring 2002 and a 2 to 7 percent decrease in credits earned in the following semesters.

Finally, Fitterman Hall, part of the Borough of Manhattan Community College (BMCC) campus, was destroyed in the attacks, leading to a loss of one-third of BMCC's classroom space. This shock to college quality may have exacerbated the negative impact of the spring 2002 price increase on undocumented students. However, in Appendix Tables A.4 and A.5, we show that our main estimates are robust to excluding BMCC students.

\subsection{Disentangling extensive and intensive margin responses to the price shock}

To better understand how much of the reduction in credits earned by senior college students was driven by decreases in reenrollment, we estimate a second set of models that condition on enrollment. We first examine whether the policy change affected the hazard of reenrollment, defined as the probability of reenrolling in semester $t$ conditional on semester $t-1$ enrollment (Table 5. Panel A). Consistent with the estimates displayed in Table 2, undocumented senior college students experienced a a 7 percentage point (7 percent) decrease in persistence in spring 2002. Among community college students, our estimates suggest that the price increase led to an insignificant 2 percentage point (2 percent) decrease in persistence. Unlike our unconditional reenrollment estimates in Table 2, we find no evidence of impacts on undocumented students' persistence after spring 2002. This is to be expected since most of the reduced rates of reenrollment in the post-spring 2002 semesters is driven by exits that occurred in spring 2002. In other words, we would not expect students who remained enrolled in the semester of the tuition hike to be more likely to leave school once the subsidy was reinstated.

Next, we examine the impact of the price increase on credits earned by enrolled students (Table 5 . Panel B) ${ }^{25}$ The price increase led to an insignificant 0.2 (2 percent) decrease in credits earned by senior college students during spring 2002. This point estimate is 23 percent of the size of the estimated impact when we do not condition on reenrollment, suggesting that the price increase primarily reduced senior college students' attainment by inducing students to leave school. In the semesters after spring 2002, enrolled senior students earned 0.3 (3 percent) fewer credits. Compared to senior college students, undocumented student enrolled in community colleges experienced larger reductions in credit accumulation, including a 0.6 credit

\footnotetext{
${ }^{25}$ Separate estimates for senior college students by initial degree program are contained in Appendix Table A.6
} 
(7 percent) decrease in spring 2002 and later semesters ${ }^{26}$ The reductions in attainment that persist after instate tuition rates were restored to undocumented students could stem from several channels. First, affected undocumented students could respond to the price increase by increasing their non-school work investments (and lowering their course loads). Alternatively, undocumented students who reenroll following the price increase could also be negatively selected, and thus, would have earned fewer credits even in the absence of the policy change. We find no effect of the price shock on enrolled students' GPA (Table 5 . Panel C) ${ }^{27}$ Our 95 percent confidence intervals rule out impacts larger than a -0.13 point decrease and a 0.05 point increase in enrolled senior college students' GPAs and a -0.07 point decrease and 0.10 point increase in enrolled community college students' GPAs in spring 2002.

The estimated impacts on credits earned and GPA capture both the effect of the policy change on attainment and effects driven through selection into the sample of enrolled students. We use student fixedeffects models to disentangle these two potentially offsetting effects. By including a student fixed effect in equation (1), our results will represent within-student variation in outcomes in spring 2002 and later semesters and exclude any contamination due to differential selection into persistence following the price shock. As shown in Appendix Table A.7, estimates impacts on credits earned and GPA from student fixedeffects models are quite similar to those displayed in Table 5, suggesting that the price shock had no effect on undocumented students' grades or credits attempted by senior college students.

We further explore selection into reenrollment in the semester of the price shock by comparing undocumented students who exited college in spring 2002 to those who exited in earlier semesters, with documented noncitizens again serving as a counterfactual. We focus on total credits earned and cumulative GPA in the semester before exit and limit our sample to senior college students, as we find no effect of the price shock on undocumented community college students' exit rates. As shown in Appendix Table A.8, relative to documented noncitizens, undocumented students who left college in spring 2002 had higher cumulative GPAs and had earned significantly more credits than those who left college prior to the price shock. If anything, these results suggest that senior college students induced to leave college due to the price shock were positively selected, on average.

\footnotetext{
${ }^{26}$ The difference in the estimated impact of the price increase on credits earned by initial degree program is marginally significant $(p=0.083)$.

${ }^{27}$ We lose a small number of student by semester observations that are missing GPA (49 senior college students and 14 community college students). We find no relationship between the probability of having a missing GPA in a semester in which the student is classified as being enrolled and the interaction between undocumented status and spring 2002 or post-spring 2002 (available upon request).
} 


\subsection{Heterogeneity by gender and race/ethnicity}

Prior research suggests greater sensitivity to tuition supports among female compared to male bachelor's degree-seeking students (e.g., Dynarski, 2008, Angrist, Lang and Oreopoulos, 2009). To determine whether the price increase had larger impacts on female undocumented students' attainment, we estimate equation (1) separately for male and female students. We find no evidence of heterogeneous impacts of the price change on senior college students' outcomes by gender (Table 6). However, among community college students, we find marginally significant heterogeneity in the impact of the price increase on spring 2002 reenrollment by gender. While the price increase did not significantly affect female undocumented students' reenrollment decisions, our estimates suggest that it led to a 5 percentage point decrease in male students' probability of reenrollment in spring 2002. We can reject the hypothesis that the interaction between undocumented status and Spring 2002 is equal for male and female students with $p=0.032$. However, in the semesters after spring 2002, when in-state rates were restored, impacts on reenrollment for male versus female community college students are not significant at conventional levels $(p=0.113)$. Additionally, among community college students, we find no evidence that the price shock had differential impacts on credits earned by gender.

Next, we test for differences in the impact of the price increase on Hispanic versus non-Hispanic students. Undocumented students in New York City are less likely to be Hispanic than undocumented students elsewhere in the US, therefore, this exercise allows us to determine how generalizable our results are to undocumented students outside of the CUNY System. Again, we estimate equation (1) separately for Hispanic and non-Hispanic students; results are displayed in Table7. Among both community and senior college students, undocumented Hispanic students' experienced the largest reduction in enrollment and credits earned in spring 2002. In the case of senior college students, differences in the impact of the price increase on credit accumulation between Hispanic and non-Hispanic students are statistically significant $(p=0.025){ }^{28}$

\subsection{Heterogeneity by entry cohort}

Finally, we test for heterogeneous impacts of the price increase by entry cohort, separately examining students who entered a CUNY institution in 1999, 2000, and 200129 Earlier cohorts potentially were able to gain experience with college and have a better idea of whether they ultimately would be successful when the price shock hit. Conversely, undocumented students in earlier cohorts may have exhausted more of their personal or family resources, leaving them more vulnerable to the unexpected price shock.

As shown in Table 8, which displays point estimates for the sample of senior college students, we find

\footnotetext{
${ }^{28}$ In Appendix Table A.9 we display results from models that separate non-Hispanic students into three additional categories: Black, Asian, and White.

${ }^{29}$ We group students by academic rather than calendar year. Thus, students entering a CUNY institution in spring 2000 are classified as entering college in 1999 and students who enter in spring 2001 are classified as 2000 entrants.
} 
evidence of heterogeneous responses by the length of time undocumented students had potentially been enrolled when the price shock occurred. For undocumented students who entered a senior college in 1999 or 2000, the price shock led to a 3 to 7 percentage point ( 5 to 7 percent) reenrollment decline in spring 2002 . However, students in these entry cohorts - who potentially had been enrolled for at least a year when the price shock hit - experienced no lasting declines in reenrollment. The estimated impacts of the price shock in the semesters after spring 2002 are small and insignificant. In other words, all of the students in the 1999 and 2000 entry cohorts induced to leave school due to the price shock were inframarginal. For 2001 entrants, the immediate impact of the price shock on reenrollment - an 8 percentage point ( 8 percent) decrease - was not statistically distinguishable from that experienced by earlier cohorts $(p=0.132)$. However, 2001 entrants also experienced lasting declines in reenrollment. Specifically, the probability of reenrollment after spring 2001 fell by 7 percentage points ( 7 percent), suggesting that close to 90 percent of the students induced to leave school by the price shock in the 2001 cohort were marginal, and would have persisted for several more semesters had they not been exposed to the tuition increase. We can reject the equality of post-spring 2002 effects across entry cohorts with $p=0.013$. We find similar patterns across entry cohorts when examining impacts on credit accumulation. We can't reject the hypothesis that the price shock had similar impacts on credit accumulation in spring 2001 across entry cohorts $(p=0.224)$, and after the in-state tuition subsidy was restored, only 2001 entrants experience lasting reductions in credits earned in a given semester.

In contrast to the patterns we observe among undocumented senior college students, we find no evidence of heterogeneous impacts of the price increase on undocumented community college students' outcomes across different entry cohorts (Table 91. Across all three entry cohorts, impacts on reenrollment are small and insignificant, while impacts on credits earned are significant (or marginally significant) and of a similar magnitude.

To further illustrate differences in the impact of the price shock on short- and longer-run attainment, we estimate event-study models in which we replace Treat ${ }_{t} \times$ Undoc $_{i}$ and Post $_{t} \times$ Undoc $_{i}$ in equation (1) with interactions between $U n d o c_{i}$ and a set of indicators for the semesters before and after the price increase (again, fall 2001 is the omitted category). In this case, we examine impacts on total credits earned (rather than credits earned in a given semester) up to 12 semesters (6 years) after the price shock. We graph these coefficients and 95 percent confidence intervals for senior and community college students separately in Figure 6. The black markers represent point estimates specific to the 2001 cohort, the hollow gray markers represent estimated impacts for 2000 entrants, and the light gray "X" markers represent point estimates for students in the 1999 entering cohort. The shaded areas represent the values contained by the 95 percent confidence intervals for each set of point estimates.

Prior to the price shock, there are no differences in cumulative credits earned between documented and 
undocumented students in community or senior colleges. As shown in Panel A, undocumented students in the 1999 entry cohort experience a small reduction in cumulative credits in spring 2001, but their credit accumulation is never statistically distinguishable from credits earned by documented students. Undocumented students belonging to the 2000 entry cohort do experience a statistically significant reduction in cumulative credits earned relative to their documented counterparts for several semesters during and following the price shock. However, differences in cumulative credits earned are no longer significant once five semesters after the tuition hike have passed. Finally, students who entered college in fall 2001 experience immediate and lasting reductions in cumulative credits earned starting in spring 2001. Even 12 semesters later, these students have earned 6 fewer credits in total than their documented peers. As shown in Panel B, we find no evidence of immediate or lasting impacts of the price shock on undocumented community college students' attainment.

\section{Longer-Run Outcomes and Degree Receipt}

In the previous section, we show that only senior college students belonging to the 2001 entry cohort experienced persistent declines in attainment following the price shock. We build upon these patterns to estimate impacts of the tuition hike on undocumented senior college students' long-run attainment, including cumulative credits earned and degree receipt eight years after entry. To do so, we compare differences in the outcomes of undocumented students who entered college in 1999 relative to cohorts that entered in 2000 and 2001, again using differences in documented noncitizens outcomes across entry cohorts to generate a counterfactual:

$$
Y_{i s c}=\alpha_{2000} \text { Undoc }_{i} \times \mathbf{1}[\text { cohort }=2000]+\alpha_{2001} U_{n d o c_{i}} \times \mathbf{1}[\text { cohort }=2001]+\boldsymbol{\eta} \mathbf{X}_{\mathbf{i}}+\psi_{s c}+\nu_{i s c}
$$

Here, $Y_{i c s}$ is cumulative credits, associate's degree receipt, and bachelor's degree receipt eight years after entry for student $i$ who initially enrolled in college $s$ as a member of cohort $c$. $U n d o c_{i}$ indicates whether a student is undocumented. The interaction between $U n d o c_{i}$ and indicators for belonging to the 2000 or 2001 entry cohort represents the treatment we are interested in estimating, with corresponding coefficients $\alpha_{2000}$ and $\alpha_{2001}$. The vector $\mathbf{X}_{\mathbf{i}}$ includes the same set of controls as in our main equation and we also control for school by cohort fixed effects, $\psi_{s c}$. Each observation represents a unique student and standard errors are clustered at the school by cohort level. We limit our sample to senior college students; results pertaining to community college students are reported in Appendix Tables A.10 and A.11.

Our identifying assumption rules out unobservable differences between students entering college in 1999 
and those entering in 2000 and 2001 that vary with documentation status and affect long-run attainment. Although this assumption is fundamentally untestable, we test whether there are differences in observable characteristics along these dimensions; estimates are displayed in Table 10 . We find no evidence of statistically significant changes in the observable characteristics of students by entry cohort that vary by undocumented status and entry and we do not reject the hypothesis that the estimates are jointly insignificant ( $p=0.731$ for the 2000 cohort and $p=0.274$ for the 2001 cohort). Finally, this approach relies on the assumption that undocumented students who entered a senior college in 1999 were only affected by the price shock in the short-run. If some students in this entry cohort also experienced declines in long-run attainment, our estimates provide a lower bound of the true impacts of the price shock on long-run outcomes.

Table 11 provides estimates from equation (2) for three samples: Panel A for all senior college students; Panel B for senior college students who initially entered college in a bachelor's degree program, and Panel C for those that initially entered an associate's degree program. Consistent with the results displayed in Panel A of Figure (6), only undocumented students who entered college in fall 2001 accumulated fewer credits over the long-run. Relative to undocumented students who entered college in 1999, 2001 entrants earned 7 fewer credits (a 9 percent decrease). These impacts are driven by bachelor's degree seeking students, who earned 8 fewer credits (a 10 percent decrease).

The second through fourth columns present estimated impacts on degree receipt within eight years of entry. Column 2 present estimated impacts of the price shock on receipt of any credential (including certificates), while columns 3 and 4 focus on receipt of associate of arts or science (AA/AS) and bachelor of arts or science (BA/BS) degrees, respectively. Again, only undocumented students who entered college in fall 2001 experienced a reduction in long-run degree receipt. However, these impacts are substantial and include a 10 percentage point (22 percent) reduction in receipt of any degree and a marginally significant 9 percentage point (22 percent) reduction in bachelor's degree receipt. Impacts on bachelor's degree receipt are driven by bachelor's degree-seeking students, who experienced a 12 percentage point (23 percent) reduction, while associate's degree-seeking senior college students were 12 percentage points (46 percent) less likely to earn an associate's degree within eight years of entry.

\section{Conclusions}

Our results suggest that CUNY's decision to temporarily remove in-state tuition benefits reduced undocumented students' short-run attainment. Senior college students were less likely to reenroll while community college students attempted and earned fewer credits. Senior college students who entered college the semester prior to the price shock experienced lasting reductions in credit accumulation and degree receipt. 
The one semester policy change represented an $\$ 1,800$ (123 percent) tuition increase for full-time senior college students. During the semester of the price shock, senior college students' reenrollment rates fell by 6.5 percentage points, which translates into an 8 percent decrease from the fall 2001 reenrollment rate. The magnitude of this effect is at the upper end of recent estimates from Goldrick-Rab et al. (2012) who find that a $\$ 1,000$ increase in financial aid to Pell-eligible students increases their persistence rates by roughly 2 to 4 percentage points.

Furthermore, undocumented students who entered a senior college the semester before the price shock also experienced reductions in long-run attainment, including a 9 percent decrease in cumulative credits earned and a 22 percent decrease in degree receipt eight years after entry. The latter effect implies a price elasticity of degree receipt equal to -0.18. Although we find evidence that the tuition increase led to a reduction in community college students' credit accumulation in spring 2002, we find no evidence of long-run reductions in their attainment. It is possible that the one-semester $\$ 300$ price increase (which represented only a 23 percent tuition hike) did not have lasting impacts on community college students' ability to regain their the credits lost in spring 2002 and graduate. Finally, we find no evidence that the tuition hike affected undocumented students' grades.

While our findings suggest that the $\$ 1,800$ in-state tuition subsidy substantially increases educational attainment for highly-constrained students with limited college experience, the benefit-to-cost ratio of this subsidy is very difficult to calculate. On the benefits side, a major question concerns the labor market returns to a college diploma for undocumented youth who currently have no permanent legal authority to live and work in the US. Even students who are enrolled in the DACA program have only temporary authorization and it is unclear whether this program will become permanent legislation. While returns to a year of college have been estimated at roughly 10 percent for an average student (e.g., Kane and Rouse 1995, Card, 1999), undocumented college graduates may experience substantially lower returns. Though the immigration policy regime may change in the future, the benefits of increasing the college attainment of undocumented are likely to accrue in non-market realms. For instance, undocumented youth who obtain college diplomas may be more civically engaged, clearly not as voters, but as consumers and participants in the informal civic and political context (e.g., Dee 2004, Milligan, Moretti and Oreopoulos 2004). In addition, assuming these undocumented youth are not deported, many are likely to have children who will be US citizens and who will benefit from having college-educated parents (e.g., Currie and Moretti 2003). In sum, the subsidy is likely to be welfare-enhancing, yet the most substantial private benefits are uncertain given these students' lack of access to formal labor markets. 


\section{References}

Abrego, Leisy Janet. 2006. "I Can't Go to College Because I Don’t Have Papers": Incorporation Patterns of Latino Undocumented Youth. Latino Studies, 4(3): 212-231.

American Community Survey. 2010. 2006-2010 American Community Survey 5-Year Estimates, Selected Characteristics of the Native and Foreign-Born Populations, New York City (Place). http://factfinder2.census.gov/faces/tableservices/jsf/pages/productview.xhtml?pid=ACS_ 10_5YR_S0501\&prodType=table, accessed September 1, 2014.

Angrist, Joshua, Daniel Lang, and Philip Oreopoulos. 2009. Incentives and Services for College Achievement: Evidence from a Randomized Trial. American Economic Journal: Applied Economics, 1(1): 136-163.

Angrist, Joshua, David Autor, Sally Hudson, and Amanda Pallais. 2014. Leveling Up: Early Results from a Randomized Evaluation of Post-Secondary Aid. NBER Working Paper 20800.

Angrist, Joshua, Philip Oreopoulos, and Tyler Williams. forthcoming. When Opportunity Knocks, Who Answers? New Evidence on College Achievement Awards. Journal of Human Resources.

Bailey, Martha J., and Susan M. Dynarski. 2011. Inequality in Postsecondary Education. In Wither Opportunity, ed. Greg J. Duncan and Richard J. Murnane, 117-132. New York, NY: Russell Sage.

Barrow, Lisa, Lashawn Richburg-Hayes, Cecilia Elena Rouse, and Thomas Brock. forthcoming. Paying for Performance: The Education Impacts of a Community College Scholarship Program for Lowincome Adults. Journal of Labor Economics.

Bettinger, Eric. 2004. How Financial Aid Affects Persistence. In College Choices: The Economics of Where to Go, When to Go, and How to Pay For It, ed. Caroline M. Hoxby. Chicago, IL: University of Chicago Press.

Bound, John, Michael F. Lovenheim, and Sarah Turner. 2010. Why Have College Completion Rates Declined? An Analysis of Changing Student Preparation and Collegiate Resources. American Economic Journal: Applied Economics, 2(3): 129-157.

Card, David. 1999. The Causal Effect of Education on Earnings. In Handbook of Labor EconomicsVol. 3A, , ed. Orley Ashenfelter and David Card, 1801-1863. Amsterdam and New York: North-Holland.

Castleman, Benjamin L., and Bridget Terry Long. 2013. Looking Beyond Enrollment: The Causal Effect of Need-based Grants on College Access, Persistence, and Graduation. NBER working paper 19306. 
Chin, Aimee, and Chinhui Juhn. 2011. Does Reducing College Costs Improve Educational Outcomes for Undocumented Immigrants? Evidence from State Laws Permitting Undocumented Immigrants to Pay In-State tuition at State Colleges and Universities. In Latinos and the Economy: Integration and Impact in Schools, Labor Markets, and Beyond, ed. David L. Leal and Stephen J. Trejo. New York, NY: Springer.

Conger, Dylan, and Colin Chellman. 2013. Undocumented College Students in the United States: In-State Tuition Not Enough to Ensure Four-Year Degree Completion. Education Finance and Policy, 8(3): $364-377$.

Contreras, Frances. 2009. Sin Papeles y Rompiendo Barreras: Latino Students and the Challenges of Persisting in College. Harvard Educational Review, 79(4): 601-631.

Currie, Janet, and Enrico Moretti. 2003. Mother's Education and the Intergenerational Transmission of Human Capital: Evidence from College Openings. Quarterly Journal of Economics, 118(4): 1495-1532.

Darolia, Rajeev, and Stephanie Potochnick. 2014. Dreams Deferred? The Educational and Financial Implications of In-State-Resident Tuition Policies for Latino Undocumented Immigrants. Paper presented at the Association for Education Finance and Policy annual meeting, San Antonio, TX.

Dee, Thomas S. 2004. Are there Civic Returns to Education? Journal of Public Economics, 88: 1697-1720.

Deming, David, and Susan Dynarski. 2010. Into College, Out of Poverty? Policies to increase Postsecondary Attainment of the Poor. In Targeting Investments in Children: Fighting Poverty When Resources are Limited, ed. Phillip Levine and David Zimmerman. Chicago, IL: University of Chicago Press.

DiNapoli, Thomas P., and Kenneth B. Bleiwas. 2014. Update: The New York State DREAM Act. http://osc.state.ny.us/osdc/rpt11-2014.pdf, accessed January 18, 2015.

Dynarski, Susan. 2008. Building the Stock of College-Educated Labor. Journal of Human Resources, 43(3): 576-610.

Flores, Stella M. 2010. State Dream Acts: The Effect of In-State Resident Tuition Policies and Undocumented Latino Students. Review of Higher Education, 33(2): 239-283.

Goldrick-Rab, Sara, Douglas N. Harris, Robert Kelchen, and James Benson. 2012. Need-Based Financial Aid and College Persistence: Experimental Evidence from Wisconsin. Working paper.

Gonzales, Roberto G. 2011. Learning to be Illegal: Undocumented Youth and Shifting Legal Contexts in the Transition to Adulthood. American Sociological Review, 76(4): 602-619. 
Hemelt, Steven W., and David E. Marcotte. 2011. The Impact of Tuition Increases on Enrollment at Public Colleges and Universities. Educational Evaluation and Policy Analysis, 33(4): 435-457.

Kane, Thomas J., and Cecilia Elena Rouse. 1995. Labor-Market Returns to Two- and Four-Year College. American Economic Review, 85(3): 600-614.

Kao, Grace, and Marta Tienda. 1995. Optimism and Achievement: The Educational Performance of Immigrant Youth. Social Science Quarterly, 76(1): 1-19.

Kaushal, Neeraj. 2008. In-state Tuition for the Undocumented: Education Effects on Mexican Young Adults. Journal of Policy Analysis and Management, 27(4): 771-792.

Marx, Benjamin M., and Lesley J. Turner. 2015. Borrowing Trouble? Student Loans, the Cost of Borrowing, and Implications for the Effectiveness of Need-Based Grant Aid. NBER working paper 20850.

Milligan, Kevin, Enrico Moretti, and Philip Oreopoulos. 2004. Does Education Improve Citizenship? Evidence from the United States and the United Kingdom. Journal of Public Economics, 88(9-10): 16671695.

Muñoz, Susana María, and Marta María Maldonado. 2012. Counterstories of College Persistence by Undocumented Mexicana Students: Navigating Race, Class, Gender, and Legal Status. International Journal of Qualitative Studies in Education, 25(3): 293-315.

Passel, Jeffrey, and D'Vera Cohn. 2010. Unauthorized Immigrant Population: National and State Trends. www.pewhispanic.org/2011/02/01/ unauthorized-immigrant-population-brnational-and-state-trends-2010/, accessed: September 23, 2014. Washington, DC: Pew Hispanic Center.

Passel, Jeffrey S., and Mark Hugo Lopez. 2012. Up to 1.7 Million Unauthorized Immigrant Youth May Benefit from New Deportation Rules. http://www.pewhispanic.org/2012/08/14/ up-to-1-7-million-unauthorized-immigrant-youth-may-benefit-from-new-deportation-rules/, accessed: December 15, 2014. Washington, DC: Pew Hispanic Center.

Patel, Reshma, and Timothy Rudd. 2012. Can Scholarships Alone Help Students Succeed? Lessons from Two New York City Community Colleges. New York and Oakland: MDRC.

Perez, William. 2009. We ARE Americans: Untold Stories of Undocumented Students in Pursuit of the American Dream. Sterling, VA: Stylus Publishing. 
Rincón, Alejandra. 2008. Undocumented Immigrants and Higher Education: ¡Si Se Puede! El Paso, TX:

LFB Scholarly Publishing LLC.

Schwartz, Amy Ellen, and Leanna Stiefel. 2006. Is There a Nativity Gap? Achievement of New York City Elementary and Middle School Immigrant Students. Education Finance and Policy, 1(1): 17-49.

Scott-Clayton, Judith. 2011. On Money and Motivation: A Quasi-Experimental Analysis of Financial Incentives for College Achievement. Journal of Human Resources, 46(3): 614-46.

Stinebrickner, Ralph, and Todd Stinebrickner. 2008. The Effect of Credit Constraints on the College Drop-Out Decision: A Direct Approach Using a New Panel Study. American Economic Review, 98(5): 2163-2184.

Watson, Tara. 2014. Inside the Refrigerator: Immigration Enforcement and Chilling Effects in Medicaid Participation. American Economic Journal: Economic Policy, 6(3): 313-338.

\section{Figures and Tables}

Figure 1: Trends in Reenrollment by Citizenship and Documentation
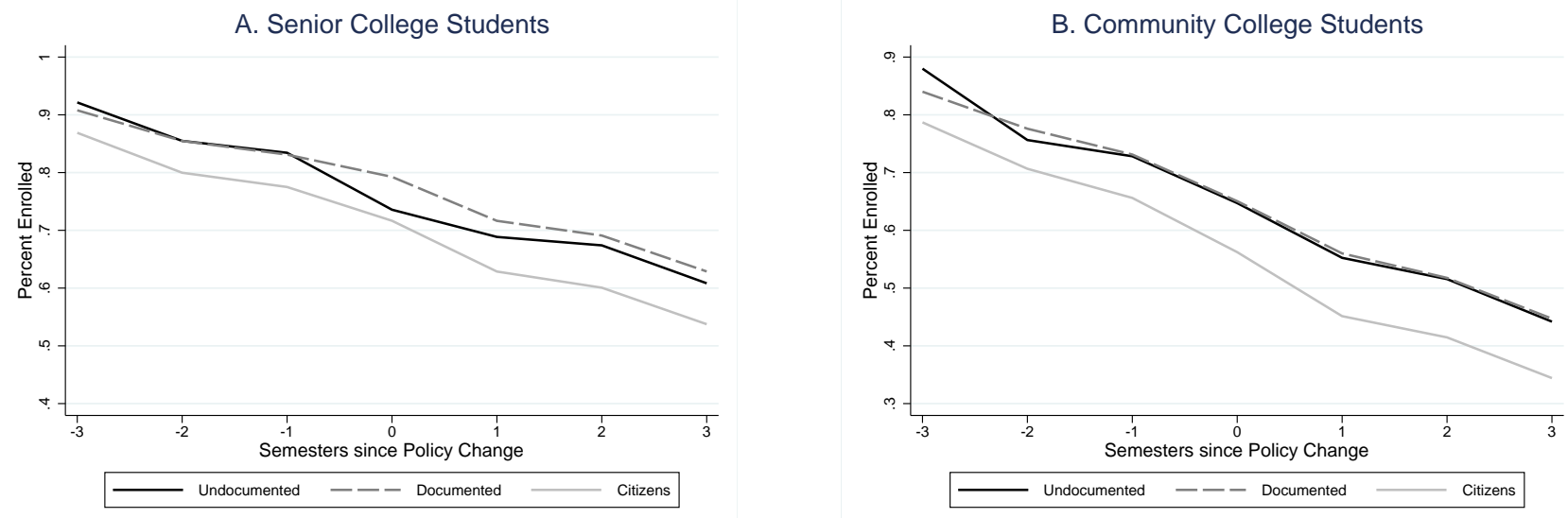

Source: CUNY administrative data. Notes: Sample includes first-time CUNY undergraduate degree-seeking students belonging to the Fall 1999 through Fall 2002 entering cohorts who earned a high school diploma or GED from New York State. Each line in Panels A and B represents the share of students in the specified group who were enrolled in the specified semester. Spring 2002 is represented by " 0 ". The sample in Panel A is limited to students who initially enrolled in a senior college. The sample in Panel B is limited to students who initially enrolled in a community college. See text for definitions of documented and undocumented noncitizens. Student by semester observations following degree receipt are dropped. 
Figure 2: Trends in Credits Attempted by Citizenship and Documentation

A. Senior College Students

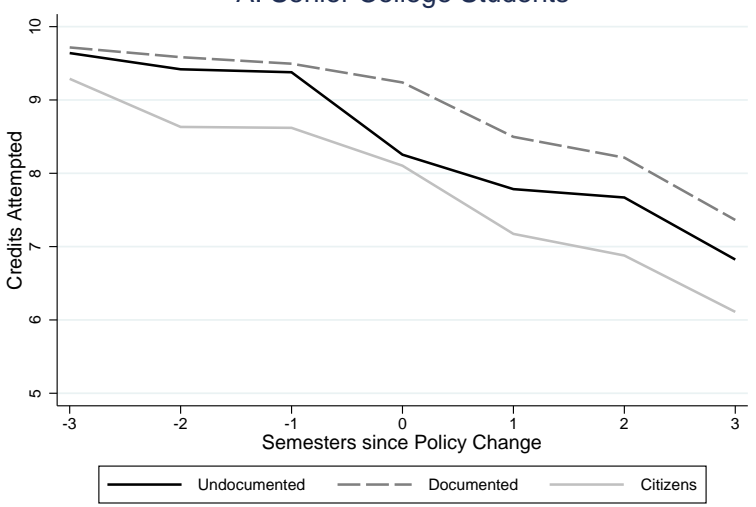

B. Community College Students

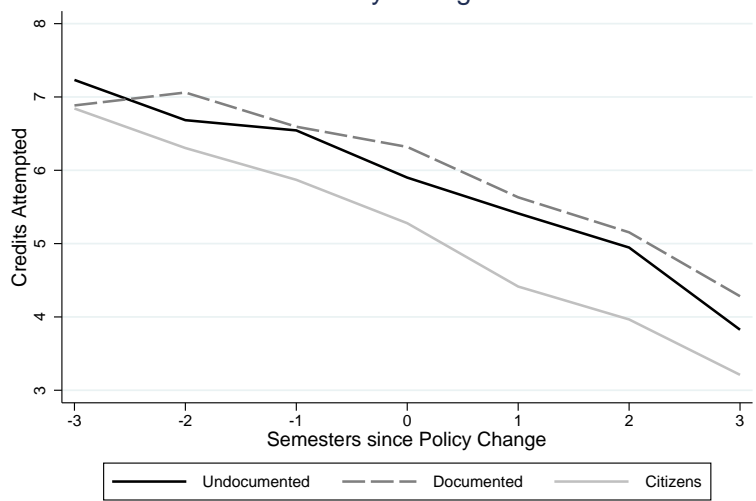

Source: CUNY administrative data. Notes: Sample includes first-time CUNY undergraduate degree-seeking students who belonged to the Fall 1999 through Fall 2002 entering cohorts and earned a high school diploma or GED from New York State. Each line in Panels A and B represents average credits attempted by students in the specified group and semester. Spring 2002 is represented by " 0 ". The sample in Panel A is limited to students who initially enrolled in a senior college. The sample in Panel B is limited to students who initially enrolled in a community college. See text for definitions of documented and undocumented noncitizens. Student by semester observations following degree receipt are dropped.

Figure 3: Trends in Credits Earned by Citizenship and Documentation

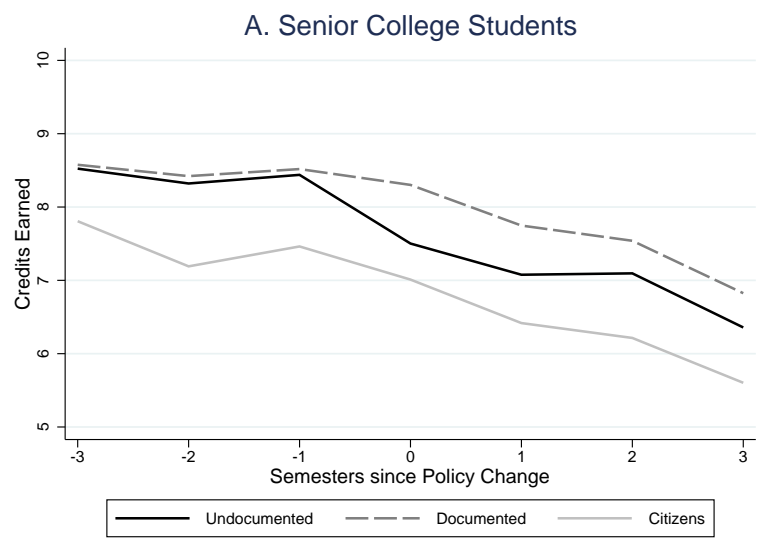

B. Community College Students

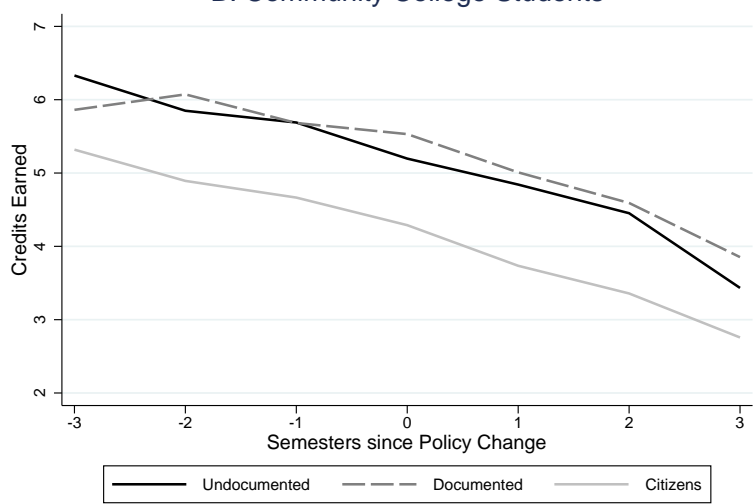

Source: CUNY administrative data. Notes: Sample includes first-time CUNY undergraduate degree-seeking students who belonged to the Fall 1999 through Fall 2002 entering cohorts and earned a high school diploma or GED from New York State. Each line in Panels A and B represents average credits earned by students in the specified group and semester. Spring 2002 is represented by "0". The sample in Panel A is limited to students who initially enrolled in a senior college. The sample in Panel $\mathrm{B}$ is limited to students who initially enrolled in a community college. See text for definitions of documented and undocumented noncitizens. Student by semester observations following degree receipt are dropped. 
Figure 4: Estimated Impacts of the Price Shock on Reenrollment by Semester
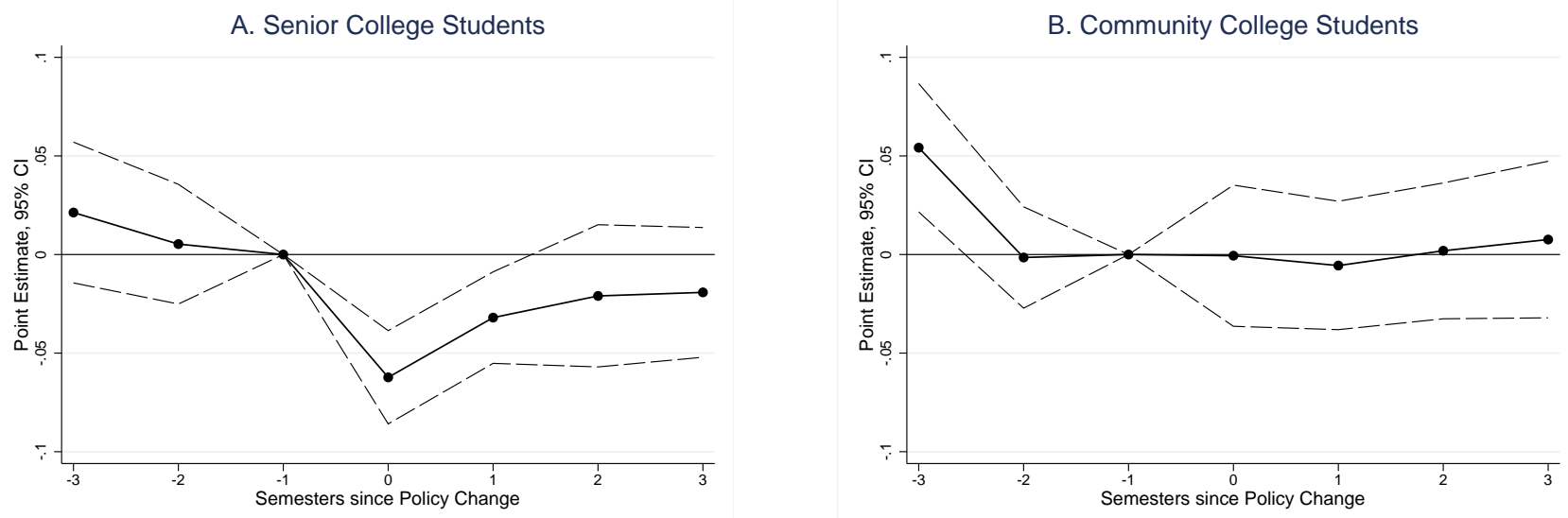

Source: CUNY administrative data. Notes: Sample includes first-time CUNY noncitizen undergraduate degree-seeking students belonging to the Fall 1999 through Fall 2002 entering cohorts who earned a high school diploma or GED from New York State. Each marker in Panels A and B represents the point estimate from a modified version of equation (1), where an indicator for undocumented status is interacted with indicators for semesters before/after spring 2002 (with fall 2001 serving as the omitted category). Spring 2002 is represented by "0". The thin dashed line represents the corresponding 95 percent confidence interval. The sample in Panel A is limited to students who initially enrolled in a senior college. The sample in Panel B is limited to students who initially enrolled in a community college. See text for definitions of documented and undocumented noncitizens. Student by semester observations following degree receipt are dropped.

Figure 5: Estimated Impacts of the Price Shock on Credits Earned by Semester
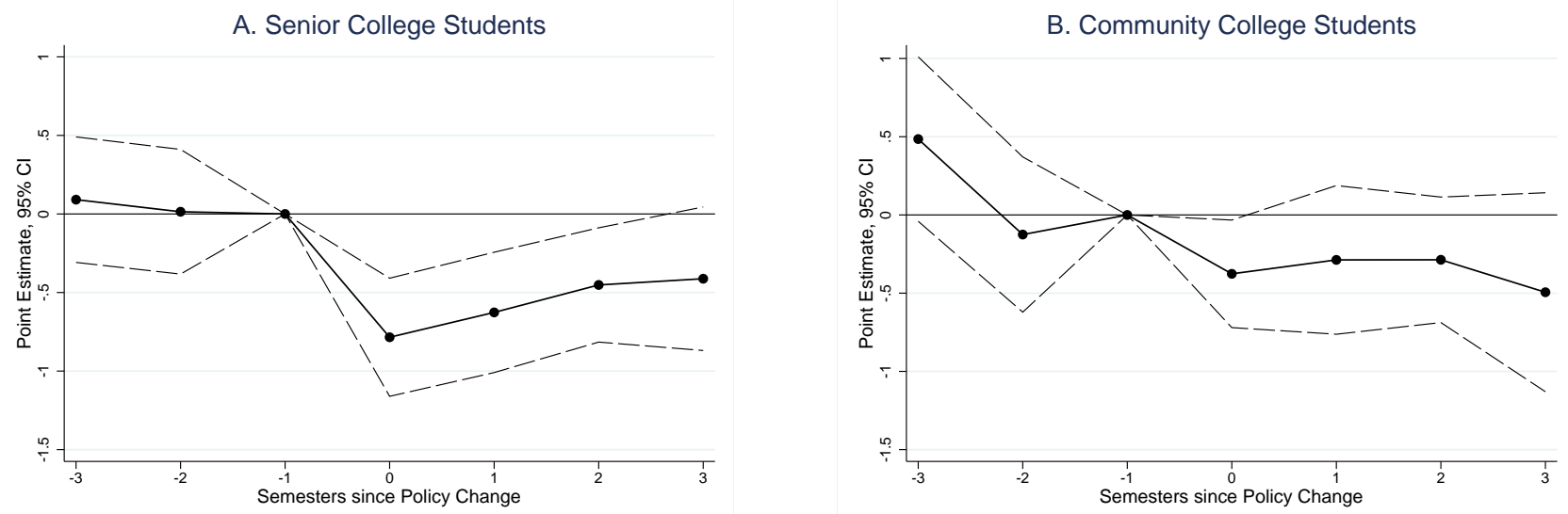

Source: CUNY administrative data. Notes: Sample includes first-time CUNY noncitizen undergraduate degree-seeking students who belonged to the Fall 1999 through Fall 2002 entering cohorts and earned a high school diploma or GED from New York State. Each marker in Panels C and D represents the point estimate from a modified version of equation (1), where an indicator for undocumented status is interacted with indicators for semesters before/after spring 2002 (with fall 2001 serving as the omitted category). Spring 2002 is represented by "0". The thin dashed line represents the corresponding 95 percent confidence interval. The sample in Panel A is limited to students who initially enrolled in a senior college. The sample in Panel B is limited to students who initially enrolled in a community college. See text for definitions of documented and undocumented noncitizens. Student by semester observations following degree receipt are dropped. 
Figure 6: Cumulative Credits Earned by Semesters Since Entry and Entry Cohort

\section{A. Senior College Students}

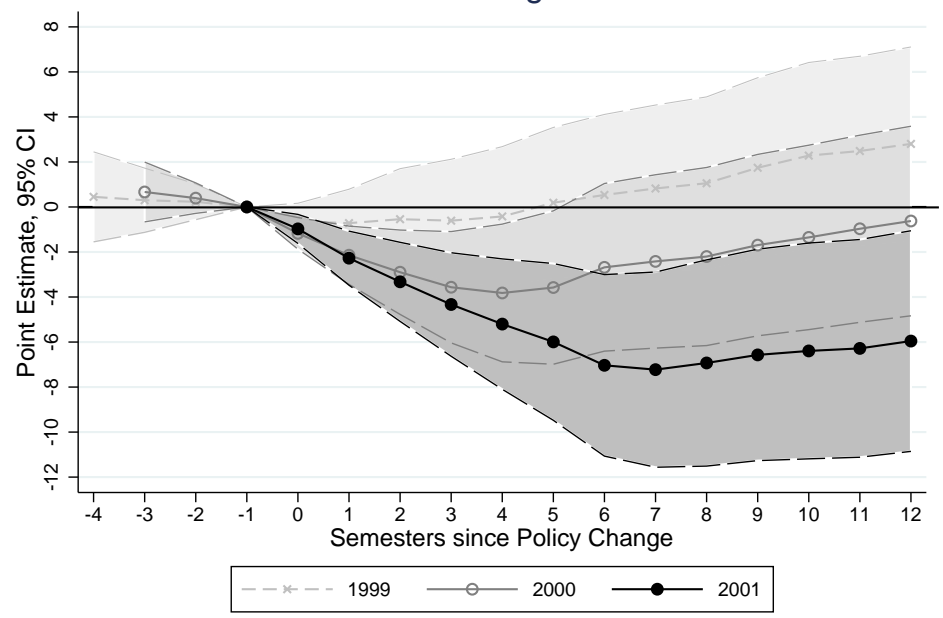

\section{B. Community College Students}

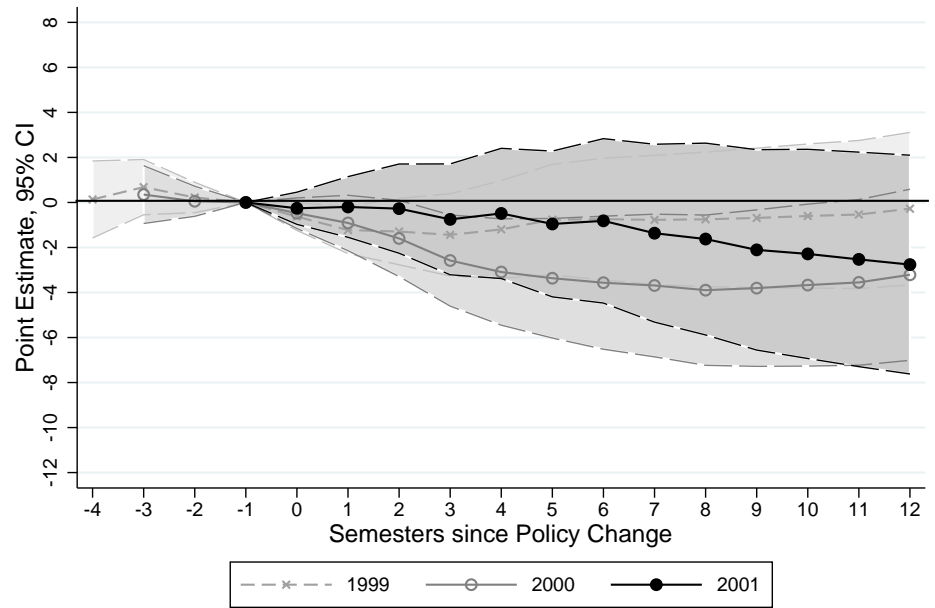

Source: CUNY administrative data. Notes: Sample includes first-time CUNY noncitizen undergraduate degree-seeking students who belonged to the Fall 1999 through Fall 2002 entering cohorts and earned a high school diploma or GED from New York State. Spring 2002 is represented by "0". Each marker represents the point estimate from a modified version of equation (11, where an indicator for undocumented status is interacted with indicators for semesters before/after spring 2002 (with fall 2001 serving as the omitted category) and the sample is limited to students who entered college in the specified semester. The thin dashed line and shaded area represents corresponding 95 percent confidence intervals. The sample in Panel A (B) is limited to students who initially enrolled in a senior (community) college. 
Table 1: Characteristics of Students by Citizenship and Documentation Status at Entry

\begin{tabular}{|c|c|c|c|c|c|c|c|}
\hline & & \multirow[b]{2}{*}{ (1) Citizens } & \multicolumn{2}{|c|}{ Noncitizens } & \multicolumn{3}{|c|}{ Tests of equality ( $p$-value) } \\
\hline & & & (2) Documented & (3) Undocumented & $\begin{array}{c}\text { Citizen vs. } \\
\text { noncitizens }\end{array}$ & $\begin{array}{l}\text { Documented } \\
\text { vs. undoc. }\end{array}$ & $\begin{array}{l}\text { All three } \\
\text { groups }\end{array}$ \\
\hline & Age & 19 & 20 & 20 & $<0.001$ & 0.505 & $<0.001$ \\
\hline & Female & 0.58 & 0.58 & 0.59 & 0.470 & 0.678 & 0.707 \\
\hline & Race/ethnicity: & & & & & & \\
\hline & Asian/Pacific Islander & 0.08 & 0.25 & 0.23 & $<0.001$ & 0.030 & $<0.001$ \\
\hline & Black & 0.30 & 0.28 & 0.34 & $<0.001$ & $<0.001$ & $<0.001$ \\
\hline & Hispanic & 0.33 & 0.28 & 0.28 & $<0.001$ & 0.856 & $<0.001$ \\
\hline & White & 0.29 & 0.18 & 0.15 & $<0.001$ & $<0.001$ & $<0.001$ \\
\hline & Single parent & 0.03 & 0.03 & 0.02 & 0.194 & 0.136 & 0.149 \\
\hline & Disabled & 0.03 & 0.02 & 0.02 & $<0.001$ & 0.148 & $<0.001$ \\
\hline & Foreign-born & 0.08 & 1 & 1 & & & \\
\hline & Permanent resident & -- & 0.93 & -- & -- & -- & -- \\
\hline & Visa-holder & -- & 0.07 & -- & -- & -- & -- \\
\hline & Refugee & -- & $<0.01$ & -- & -- & -- & -- \\
\hline \multirow{14}{*}{ ڤ્ } & High school type: & & & & & & \\
\hline & NYC public & 0.65 & 0.77 & 0.75 & $<0.001$ & 0.008 & $<0.001$ \\
\hline & NYC private & 0.15 & 0.04 & 0.03 & $<0.001$ & 0.650 & $<0.001$ \\
\hline & NY state & 0.05 & 0.02 & 0.03 & $<0.001$ & 0.001 & $<0.001$ \\
\hline & GED & 0.15 & 0.17 & 0.19 & $<0.001$ & 0.066 & $<0.001$ \\
\hline & High school GPA (0-100) & 76 & 77 & 77 & $<0.001$ & 0.078 & $<0.001$ \\
\hline & Missing high school GPA & 0.05 & 0.04 & 0.05 & 0.002 & 0.001 & $<0.001$ \\
\hline & Bachelor's degree program & 0.37 & 0.35 & 0.30 & $<0.001$ & $<0.001$ & $<0.001$ \\
\hline & Initial institution selectivity: & & & & & & \\
\hline & Very competitive & 0.06 & 0.07 & 0.05 & $<0.001$ & $<0.001$ & $<0.001$ \\
\hline & Competitive & 0.29 & 0.25 & 0.23 & $<0.001$ & 0.057 & $<0.001$ \\
\hline & Less/noncompetitive & 0.25 & 0.23 & 0.20 & $<0.001$ & 0.009 & $<0.001$ \\
\hline & Nonselective & 0.40 & 0.45 & 0.52 & $<0.001$ & $<0.001$ & $<0.001$ \\
\hline & Observations & 43,159 & 16,107 & 1,808 & & & \\
\hline
\end{tabular}

Source: CUNY administrative data. Notes: Sample includes first-time CUNY undergraduate degree-seeking students who earned a high school diploma or GED from New York State belonging to the Fall 1999 through Fall 2002 entering cohorts. High school GPA refers to the CUNY college admissions average, which is a standardized measure of students' high school grade point averages on a scale of 0 to 100. College competitiveness level according to the Barron's Profile of American Colleges. 
Table 2: The Impact of the Tuition Increase on Undocumented Students' Attainment

\begin{tabular}{|c|c|c|}
\hline & $\begin{array}{l}\text { (1) Senior college } \\
\text { students }\end{array}$ & $\begin{array}{l}\text { (2) Community } \\
\text { college students }\end{array}$ \\
\hline \multicolumn{3}{|l|}{ A. Reenrollment } \\
\hline Undocumented x spring 2002 & $\begin{array}{c}-0.065 \\
(0.012)^{* *}\end{array}$ & $\begin{array}{l}-0.012 \\
(0.015)\end{array}$ \\
\hline Undocumented x post-spring 2002 & $\begin{array}{c}-0.029 \\
(0.013)^{*}\end{array}$ & $\begin{array}{l}-0.006 \\
(0.013)\end{array}$ \\
\hline Test of equality ( $p$-value) & 0.005 & 0.561 \\
\hline Fall 2001 undocumented mean & 0.83 & 0.73 \\
\hline Impact in \% change: spring 2002 & $-8 \%$ & $-2 \%$ \\
\hline Impact in \% change: post-spring 2002 & $-3 \%$ & $-1 \%$ \\
\hline Observations & 61,481 & 51,090 \\
\hline \multicolumn{3}{|l|}{ B. Credits attempted } \\
\hline Undocumented $\times$ spring 2002 & $\begin{array}{c}-0.913 \\
(0.176)^{* *}\end{array}$ & $\begin{array}{c}-0.426 \\
(0.145)^{* *}\end{array}$ \\
\hline Undocumented × post-spring 2002 & $\begin{array}{c}-0.547 \\
(0.180)^{* *}\end{array}$ & $\begin{array}{c}-0.327 \\
(0.192)+\end{array}$ \\
\hline Test of equality ( $p$-value) & 0.033 & 0.558 \\
\hline Fall 2001 undocumented mean & 9.4 & 6.5 \\
\hline Impact in \% change: spring 2002 & $-10 \%$ & $-7 \%$ \\
\hline Impact in \% change: post-spring 2002 & $-6 \%$ & $-5 \%$ \\
\hline Observations & 61,481 & 51,090 \\
\hline \multicolumn{3}{|l|}{ C. Credits earned } \\
\hline Undocumented x spring 2002 & $\begin{array}{c}-0.763 \\
(0.159)^{* *}\end{array}$ & $\begin{array}{c}-0.435 \\
(0.125)^{* *}\end{array}$ \\
\hline Undocumented × post-spring 2002 & $\begin{array}{c}-0.511 \\
(0.156)^{* *}\end{array}$ & $\begin{array}{c}-0.368 \\
(0.160)^{*}\end{array}$ \\
\hline Test of equality ( $p$-value) & 0.165 & 0.627 \\
\hline Fall 2001 undocumented mean & 8.4 & 5.7 \\
\hline Impact in \% change: spring 2002 & $-9 \%$ & $-8 \%$ \\
\hline Impact in \% change: post-spring 2002 & $-6 \%$ & $-6 \%$ \\
\hline Observations & 61,481 & 51,090 \\
\hline
\end{tabular}

Source: CUNY administrative data. Notes: Sample includes first-time CUNY noncitizen undergraduate degree-seeking students who earned a high school diploma or GED from New York State belonging to the Fall 1999 through Fall 2002 entering cohorts. Each column within a panel represents a separate regression. Clustered standard errors (institution by cohort) in parentheses; ** $\mathrm{p}<0.01, * \mathrm{p}<0.05,+\mathrm{p}<0.1$. Reported coefficients are interactions between an indicator for whether a student is an undocumented noncitizen at college entry and Spring 2002 and undocumented status with post-Spring 2002. All regressions also include controls for age at entry, high school GPA (set to zero if missing), an indicator for whether a student's high school GPA is missing, indicators for race/ethnicity (Black, Hispanic, or White) and gender, an indicator for initial degree program (associate's versus bachelor's degree), indicators for whether the student was a single parent, needed remediation, was undocumented, or was disabled at entry, semester fixed effects, institution by cohort fixed effects, and cohort-specific time trends. The sample of senior college students includes those who initially enrolled in Baruch, Brooklyn, City, Hunter, John Jay, Queens, Lehman, City College of Technology, Staten Island, or York Colleges. The sample of community college students include those who initially enrolled in Borough of Manhattan, Bronx, Hostos, Kingsborough, LaGuardia, or Queensborough Community Colleges. Student by semester observations are dropped following degree receipt. 
Table 3: Robustness of Estimated Impacts on Reenrollment

\begin{tabular}{lccc}
\hline & $\begin{array}{c}\text { (1) Student fixed } \\
\text { effects }\end{array}$ & $\begin{array}{c}\text { (2) Larger window } \\
(+/-4 \text { semesters) }\end{array}$ & $\begin{array}{c}\text { (3) Smaller window } \\
(+/-2 \text { semesters) }\end{array}$ \\
\hline A. Senior college students & & & \\
Undocumented x spring 2002 & -0.058 & -0.064 & -0.060 \\
& $(0.013)^{* *}$ & $(0.012)^{* *}$ & $(0.011)^{* *}$ \\
Undocumented x post-spring 2002 & -0.019 & -0.024 & -0.024 \\
& $(0.015)$ & $(0.014)+$ & $(0.014)^{+}$ \\
Test of equality (p -value) & 0.007 & 0.006 & 0.006 \\
Fall 2001 undocumented mean & 0.83 & 0.83 & 0.83 \\
Impact in \% change: spring 2002 & $-7 \%$ & $-8 \%$ & $-7 \%$ \\
Impact in \% change: post-spring 2002 & $-2 \%$ & $-3 \%$ & $-3 \%$ \\
Observations & 61,481 & 73,768 & 45,777 \\
\hline B. Community college students & & & 0.003 \\
Undocumented x spring 2002 & -0.011 & -0.009 & $(0.017)$ \\
Undocumented x post-spring 2002 & $(0.018)$ & $(0.015)$ & 0.008 \\
& -0.005 & 0.004 & $(0.015)$ \\
Test of equality (p -value) & $(0.016)$ & $(0.014)$ & 0.662 \\
Fall 2001 undocumented mean & 0.578 & 0.288 & 0.73 \\
Impact in \% change: spring 2002 & 0.73 & 0.73 & $0.4 \%$ \\
Impact in \% change: post-spring 2002 & $-2 \%$ & $-1 \%$ & $1 \%$ \\
Observations & $-1 \%$ & $1 \%$ & 38,077 \\
\hline
\end{tabular}

Source: CUNY administrative data. Notes: Sample includes first-time CUNY noncitizen undergraduate degree-seeking students who earned a high school diploma or GED from New York State belonging to the Fall 1999 through Fall 2002 entering cohorts. Each column within a panel represents a separate regression. Clustered standard errors (institution by cohort) in parentheses; ${ }^{* *} \mathrm{p}<0.01,{ }^{*} \mathrm{p}<0.05,+\mathrm{p}<0.1$. See Table 2 notes for additional control variables and definitions of senior and community college samples. Student fixed effects models also include student fixed effects. The column (2) sample is limited to students who were enrolled in the fall 2001 semester. The column (3) sample includes student by semester observations from four semesters before and after the policy change while the column (4) sample excludes student by semester observations more than two semesters before/after the policy change. Student by semester observations are dropped following degree receipt. 
Table 4: Robustness of Estimated Impacts on Credits Earned

\begin{tabular}{lccc}
\hline & $\begin{array}{c}\text { (1) Student fixed } \\
\text { effects }\end{array}$ & $\begin{array}{c}\text { (2) Larger window } \\
(+/-4 \text { semesters) }\end{array}$ & $\begin{array}{c}\text { (3) Smaller window } \\
(+/-2 \text { semesters) }\end{array}$ \\
\hline A. Senior college students & & & \\
Undocumented × spring 2002 & -0.673 & -0.738 & -0.737 \\
& $(0.170)^{* *}$ & $(0.166)^{* *}$ & $(0.165)^{* *}$ \\
Undocumented x post-spring 2002 & -0.378 & -0.412 & -0.497 \\
& $(0.187)^{*}$ & $(0.156)^{*}$ & $(0.161)^{* *}$ \\
Test of equality (p-value) & 0.141 & 0.082 & 0.212 \\
Fall 2001 undocumented mean & 8.4 & 8.4 & 8.4 \\
Impact in \% change: spring 2002 & $-8 \%$ & $-9 \%$ & $-9 \%$ \\
Impact in \% change: post-spring 2002 & $-5 \%$ & $-5 \%$ & $-6 \%$ \\
Observations & 61,481 & 73,768 & 45,777 \\
\hline B. Community college students & & & -0.285 \\
Undocumented x spring 2002 & -0.479 & -0.439 & $(0.162)+$ \\
& $(0.147)^{* *}$ & $(0.130)^{* *}$ & -0.139 \\
Undocumented x post-spring 2002 & -0.399 & -0.269 & $(0.190)$ \\
& $(0.186)^{*}$ & $(0.159)$ & 0.310 \\
Test of equality (p -value) & 0.568 & 0.257 & 5.7 \\
Fall 2001 undocumented mean & 5.7 & 5.7 & $-5 \%$ \\
Impact in \% change: spring 2002 & $-8 \%$ & $-8 \%$ & $-2 \%$ \\
Impact in \% change: post-spring 2002 & $-7 \%$ & $-5 \%$ & 38,077 \\
Observations & 51,090 & 61,711 & \\
\hline
\end{tabular}

Source: CUNY administrative data. Notes: Sample includes first-time CUNY noncitizen undergraduate degree-seeking students who earned a high school diploma or GED from New York State belonging to the Fall 1999 through Fall 2002 entering cohorts. Each column within a panel represents a separate regression. Clustered standard errors (institution by cohort) in parentheses; ${ }^{* *} \mathrm{p}<0.01,{ }^{*} \mathrm{p}<0.05,+\mathrm{p}<0.1$. See Table 3 notes for description of specifications. Student by semester observations are dropped following degree receipt. 
Table 5: The Impact of the Tuition Increase on the Attainment of Enrolled Undocumented Students

\begin{tabular}{lcc}
\hline & $\begin{array}{c}\text { (1) Senior college } \\
\text { students }\end{array}$ & $\begin{array}{c}\text { (2) Community } \\
\text { college students }\end{array}$ \\
\hline A. Pr (enrolled ${ }_{t}$ ) | enrolled ${ }_{t-1}$ & & \\
Undocumented × spring 2002 & -0.065 & -0.018 \\
& $(0.014)^{* *}$ & $(0.019)$ \\
Undocumented × post-spring 2002 & -0.007 & 0.002 \\
& $(0.011)$ & $(0.012)$ \\
Test of equality (p- value) & $<0.001$ & 0.289 \\
Fall 2001 undocumented mean & 0.90 & 0.85 \\
Impact in \% change: spring 2002 & $-7 \%$ & $-2 \%$ \\
Impact in \% change: post-spring 2002 & $-1 \%$ & $0.2 \%$ \\
Observations & 47,747 & 33,513 \\
\hline B. Credits earned | enrolled & & \\
Undocumented × Spring 2002 or later & -0.175 & -0.592 \\
& $(0.172)$ & $(0.171)^{* *}$ \\
Undocumented × Post-Spring 2002 & -0.322 & -0.558 \\
Test of equality (p- value) & $(0.174)+$ & $(0.216)^{*}$ \\
Fall 2001 undocumented mean & 0.473 & 0.874 \\
Impact in \% Change - Spring 2002 & 10.3 & 8.1 \\
Impact in \% Change - Post-Spring 2002 & $-2 \%$ & $-7 \%$ \\
Observations & $-3 \%$ & $-7 \%$ \\
\hline C. GPA | enrolled & 45,866 & 31,155 \\
Undocumented × Spring 2002 & & \\
Undocumented x Post-Spring 2002 & -0.025 & -0.007 \\
Test of equality (p- value) & $(0.032)$ & $(0.030)$ \\
Fall 2001 undocumented mean & 0.624 & 0.685 \\
Impact in \% Change - Spring 2002 & 2.57 & 2.40 \\
Observations & $-2 \%$ & $-0.3 \%$ \\
\hline
\end{tabular}

Source: CUNY administrative data. Notes: Sample includes first-time CUNY noncitizen undergraduate degree-seeking students who earned a high school diploma or GED from New York State belonging to the Fall 1999 through Fall 2002 entering cohorts. Each column within a panel represents a separate regression. Clustered standard errors (institution by cohort) in parentheses; ${ }^{* *} \mathrm{p}<0.01,{ }^{*} \mathrm{p}<0.05,+\mathrm{p}<0.1$. See Table 2 notes for additional control variables and definitions of senior and community college samples. Student by semester observations are dropped following degree receipt. Panel A sample conditions on enrollment in semester $t-1$. Panels B and C samples condition on enrollment in semester $t$. 
Table 6: Heterogeneity in the Impact of the Tuition Increase by Gender

\begin{tabular}{|c|c|c|c|c|c|c|}
\hline & \multicolumn{3}{|c|}{$\underline{\text { Senior college students }}$} & \multicolumn{3}{|c|}{$\underline{\text { Community college students }}$} \\
\hline & (1) Female & (2) Male & $\begin{array}{c}\text { Test of eq. } \\
(p \text {-value })\end{array}$ & (3) Female & (4) Male & $\begin{array}{l}\text { Test of eq. } \\
\text { ( } p \text {-value) }\end{array}$ \\
\hline \multicolumn{7}{|l|}{ A. Reenrollment } \\
\hline Undocumented × spring 2002 & $\begin{array}{c}-0.073 \\
(0.016)^{* *}\end{array}$ & $\begin{array}{c}-0.054 \\
(0.018)^{* *}\end{array}$ & 0.447 & $\begin{array}{c}0.011 \\
(0.018)\end{array}$ & $\begin{array}{c}-0.046 \\
(0.023)+\end{array}$ & 0.032 \\
\hline Undocumented × post-spring 2002 & $\begin{array}{c}-0.035 \\
(0.016)^{*}\end{array}$ & $\begin{array}{l}-0.020 \\
(0.019)\end{array}$ & 0.515 & $\begin{array}{c}0.012 \\
(0.015)\end{array}$ & $\begin{array}{c}-0.032 \\
(0.023)\end{array}$ & 0.113 \\
\hline Fall 2001 undocumented mean & 0.84 & 0.83 & & 0.75 & 0.70 & \\
\hline Observations & 35,290 & 26,191 & & 30,379 & 20,711 & \\
\hline \multicolumn{7}{|l|}{ B. Credits earned } \\
\hline Undocumented x spring 2002 & $\begin{array}{c}-0.881 \\
(0.209)^{* *}\end{array}$ & $\begin{array}{c}-0.591 \\
(0.280)^{*}\end{array}$ & 0.422 & $\begin{array}{c}-0.385 \\
(0.184)^{*}\end{array}$ & $\begin{array}{c}-0.518 \\
(0.277)+\end{array}$ & 0.731 \\
\hline Undocumented x post-spring 2002 & $\begin{array}{c}-0.548 \\
(0.172)^{* *}\end{array}$ & $\begin{array}{c}-0.457 \\
(0.262)+\end{array}$ & 0.757 & $\begin{array}{l}-0.352 \\
(0.214)\end{array}$ & $\begin{array}{c}-0.393 \\
(0.281)\end{array}$ & 0.911 \\
\hline Fall 2001 undocumented mean & 8.9 & 7.9 & & 6.4 & 4.7 & \\
\hline Observations & 35,290 & 26,191 & & 30,379 & 20,711 & \\
\hline
\end{tabular}

Source: CUNY administrative data. Notes: Sample includes first-time CUNY noncitizen undergraduate degree-seeking students who earned a high school diploma or GED from New York State belonging to the Fall 1999 through Fall 2002 entering cohorts. Each column within a panel represents a separate regression. Clustered standard errors (institution by cohort) in parentheses; ${ }^{* *} \mathrm{p}<0.01,{ }^{*} \mathrm{p}<0.05,+\mathrm{p}<0.1$. See Table 2 notes for description of control variables and specification. 
Table 7: Heterogeneity in the Impact of the Tuition Increase by Hispanic Ethnicity

\begin{tabular}{|c|c|c|c|c|c|c|}
\hline & \multicolumn{3}{|c|}{$\underline{\text { Senior college students }}$} & \multicolumn{3}{|c|}{$\underline{\text { Community college students }}$} \\
\hline & $\begin{array}{c}(1) \\
\text { Hispanic }\end{array}$ & $\begin{array}{l}\text { (2) Non- } \\
\text { hispanic }\end{array}$ & $\begin{array}{c}\text { Test of eq. } \\
(p \text {-value) }\end{array}$ & $\begin{array}{c}(1) \\
\text { Hispanic } \\
\end{array}$ & $\begin{array}{l}\text { (2) Non- } \\
\text { hispanic }\end{array}$ & $\begin{array}{c}\text { Test of eq. } \\
\text { (p-value) }\end{array}$ \\
\hline \multicolumn{7}{|l|}{ A. Reenrollment } \\
\hline Undocumented × spring 2002 & $\begin{array}{c}-0.083 \\
(0.024)^{* *}\end{array}$ & $\begin{array}{c}-0.058 \\
(0.015)^{* *}\end{array}$ & 0.414 & $\begin{array}{c}-0.031 \\
(0.028)\end{array}$ & $\begin{array}{c}-0.004 \\
(0.015)\end{array}$ & 0.333 \\
\hline Undocumented × post-spring 2002 & $\begin{array}{c}0.002 \\
(0.031)\end{array}$ & $\begin{array}{c}-0.037 \\
(0.015)^{*}\end{array}$ & 0.280 & $\begin{array}{l}-0.019 \\
(0.028)\end{array}$ & $\begin{array}{c}-0.001 \\
(0.017)\end{array}$ & 0.606 \\
\hline Fall 2001 undocumented mean & 0.83 & 0.84 & & 0.71 & 0.74 & \\
\hline Observations & 13,189 & 48,292 & & 19,049 & 32,041 & \\
\hline \multicolumn{7}{|l|}{ B. Credits earned } \\
\hline Undocumented × spring 2002 & $\begin{array}{c}-1.384 \\
(0.318)^{* *}\end{array}$ & $\begin{array}{c}-0.541 \\
(0.189)^{* *}\end{array}$ & 0.025 & $\begin{array}{c}-0.596 \\
(0.324)+\end{array}$ & $\begin{array}{c}-0.330 \\
(0.145)^{*}\end{array}$ & 0.487 \\
\hline Undocumented x post-spring 2002 & $\begin{array}{c}-0.583 \\
(0.346)+\end{array}$ & $\begin{array}{c}-0.482 \\
(0.176)^{* *}\end{array}$ & 0.799 & $\begin{array}{c}-0.952 \\
(0.274)^{* *}\end{array}$ & $\begin{array}{c}-0.033 \\
(0.244)\end{array}$ & 0.911 \\
\hline Fall 2001 undocumented mean & 8.1 & 8.6 & & 5.1 & 5.9 & \\
\hline Observations & 13,189 & 48,292 & & 19,049 & 32,041 & \\
\hline
\end{tabular}

Source: CUNY administrative data. Notes: Sample includes first-time CUNY noncitizen undergraduate degree-seeking students who earned a high school diploma or GED from New York State belonging to the Fall 1999 through Fall 2002 entering cohorts.

Each column within a panel represents a separate regression. Clustered standard errors (institution by cohort) in parentheses; ${ }^{* *} \mathrm{p}<0.01,{ }^{*} \mathrm{p}<0.05,+\mathrm{p}<0.1$. See Table 2 notes for description of control variables and specification. 
Table 8: Heterogeneity in the Impact of the Tuition Increase by Entry Year: Senior College Students

\begin{tabular}{lcccc}
\hline & $(1) 1999$ & $(2) 2000$ & (3) 2001 & $\begin{array}{c}\text { Test of eq. } \\
\text { (p-value) }\end{array}$ \\
\cline { 2 - 5 } A. Reenrollment & & & & \\
Undocumented x spring 2002 & -0.033 & -0.073 & -0.084 & 0.132 \\
& $(0.020)$ & $(0.020)^{* *}$ & $(0.018)^{* *}$ & \\
Undocumented x post-spring 2002 & -0.002 & -0.009 & -0.073 & 0.013 \\
& $(0.022)$ & $(0.022)$ & $(0.018)^{* *}$ & \\
Test of equality (p- value) & 0.119 & 0.011 & 0.549 & \\
Fall 2001 undocumented mean & 0.68 & 0.79 & 1.00 & \\
Impact in \% change: spring 2002 & $-5 \%$ & $-9 \%$ & $-8 \%$ & \\
Impact in \% change: post-spring 2002 & $-0.3 \%$ & $-1 \%$ & $-7 \%$ & \\
Observations & 21,586 & 24,539 & 15,356 & \\
\hline B. Credits earned & & & & \\
Undocumented x spring 2002 & -0.452 & -0.937 & -0.928 & 0.224 \\
& $(0.216)^{*}$ & $(0.216)^{* *}$ & $(0.354)^{*}$ & \\
Undocumented x post-spring 2002 & 0.181 & -0.546 & -1.072 & $<0.001$ \\
Test of equality (p- value): & $(0.271)$ & $(0.283)+$ & $(0.155)^{* *}$ & \\
Fall 2001 undocumented mean & 0.071 & 0.19 & 0.642 & \\
Impact in \% change: spring 2002 & 7.0 & 8.0 & 10.0 & \\
Impact in \% change: post-spring 2002 & $-6 \%$ & $-12 \%$ & $-9 \%$ & \\
Observations & $3 \%$ & $-7 \%$ & $-11 \%$ & \\
\hline
\end{tabular}

Source: CUNY administrative data. Notes: Sample includes first-time CUNY noncitizen undergraduate degree-seeking senior college students who earned a high school diploma or GED from New York State belonging to the Fall 1999 through Fall 2002 senior college entering cohorts. Each column within a panel represents a separate regression. Clustered standard errors by student in parentheses; ${ }^{*} \mathrm{p}<0.01,{ }^{*} \mathrm{p}<0.05,+\mathrm{p}<0.1$. See Table 2 notes for description of control variables and specification. 
Table 9: Heterogeneity in the Impact of the Tuition Increase by Entry Year: Community College Students

\begin{tabular}{lcccc}
\hline & $(1) 1999$ & $(2) 2000$ & (3) 2001 & $\begin{array}{c}\text { Test of eq. } \\
\text { ( } p \text { - value) }\end{array}$ \\
\hline A. Reenrollment & & & & \\
$\quad$ Undocumented x spring 2002 & -0.017 & -0.011 & -0.011 & 0.979 \\
& $(0.028)$ & $(0.030)$ & $(0.013)$ & \\
Undocumented x post-spring 2002 & -0.002 & -0.008 & -0.014 & 0.921 \\
& $(0.027)$ & $(0.020)$ & $(0.015)$ & \\
Test of equality (p- value) & 0.314 & 0.887 & 0.814 & \\
Fall 2001 undocumented mean & 0.53 & 0.70 & 1.00 & \\
Impact in \% change: spring 2002 & $-3 \%$ & $-2 \%$ & $-1 \%$ & \\
Impact in \% change: post-spring 2002 & $-0.4 \%$ & $-1 \%$ & $-1 \%$ & \\
Observations & 21,737 & 19,831 & 9,522 & \\
\hline B. Credits earned & & & & \\
Undocumented x spring 2002 & -0.581 & -0.575 & -0.492 & 0.975 \\
& $(0.194)^{*}$ & $(0.283)+$ & $(0.379)$ & \\
Undocumented x post-spring 2002 & -0.213 & -0.744 & -0.387 & 0.306 \\
& $(0.300)$ & $(0.208) * *$ & $(0.533)$ & \\
Test of equality (p- value) & 0.234 & 0.417 & 0.691 & \\
Fall 2001 undocumented mean & 4.9 & 6.1 & 6.2 & \\
Impact in \% change: spring 2002 & $-12 \%$ & $-9 \%$ & $-8 \%$ & \\
Impact in \% change: post-spring 2002 & $-4 \%$ & $-12 \%$ & $-6 \%$ & \\
Observations & 21,737 & 19,831 & 9,522 & \\
\hline
\end{tabular}

Source: CUNY administrative data. Notes: Sample includes first-time CUNY noncitizen undergraduate degree-seeking community college students who earned a high school diploma or GED from New York State belonging to the Fall 1999 through Fall 2002 entering cohorts. Students classified as Native American are dropped. Each column within a panel represents a separate regression. Clustered standard errors (institution by cohort) in parentheses; ${ }^{* *} \mathrm{p}<0.01,{ }^{*} \mathrm{p}<0.05,+\mathrm{p}<0.1$. Brackets contain $p$-values from test of equality of treatment variables by race/ethnicity categories. See Table 2 notes for description of control variables and specification. All control variables are fully interacted with indicators for whether a student is Hispanic. 
Table 10: Changes in Observed Characteristics between Affected and Unaffected Undocumented Entry Cohorts: Senior College Students

\begin{tabular}{|c|c|c|}
\hline & $\begin{array}{l}\text { Undocumented x } \\
2000 \text { entrant }\end{array}$ & $\begin{array}{l}\text { Undocumented } \times \\
2001 \text { entrant }\end{array}$ \\
\hline \multicolumn{3}{|l|}{ Dependent var: } \\
\hline Age & $\begin{array}{c}0.035 \\
(0.196)\end{array}$ & $\begin{array}{c}0.328 \\
(0.250)\end{array}$ \\
\hline Female & $\begin{array}{c}0.025 \\
(0.049)\end{array}$ & $\begin{array}{c}0.061 \\
(0.041)\end{array}$ \\
\hline Black & $\begin{array}{c}0.001 \\
(0.042)\end{array}$ & $\begin{array}{c}0.025 \\
(0.046)\end{array}$ \\
\hline Hispanic & $\begin{array}{c}0.045 \\
(0.035)\end{array}$ & $\begin{array}{c}0.019 \\
(0.037)\end{array}$ \\
\hline White & $\begin{array}{l}-0.031 \\
(0.047)\end{array}$ & $\begin{array}{l}-0.043 \\
(0.048)\end{array}$ \\
\hline Single Parent & $\begin{array}{l}-0.006 \\
(0.005)\end{array}$ & $\begin{array}{c}0.003 \\
(0.010)\end{array}$ \\
\hline Needs remediation & $\begin{array}{l}-0.023 \\
(0.039)\end{array}$ & $\begin{array}{l}-0.028 \\
(0.037)\end{array}$ \\
\hline Disabled & $\begin{array}{l}-0.018 \\
(0.019)\end{array}$ & $\begin{array}{l}-0.026 \\
(0.018)\end{array}$ \\
\hline High school GPA & $\begin{array}{c}0.843 \\
(0.828)\end{array}$ & $\begin{array}{c}0.657 \\
(0.681)\end{array}$ \\
\hline Missing hs GPA & $\begin{array}{l}-0.005 \\
(0.009)\end{array}$ & $\begin{array}{l}-0.004 \\
(0.007)\end{array}$ \\
\hline NYC public high school & $\begin{array}{c}0.019 \\
(0.035)\end{array}$ & $\begin{array}{c}0.036 \\
(0.028)\end{array}$ \\
\hline GED & $\begin{array}{l}-0.026 \\
(0.018)\end{array}$ & $\begin{array}{l}-0.000 \\
(0.014)\end{array}$ \\
\hline Test of joint sig. (p-val.) & 0.731 & 0.274 \\
\hline Observations & \multicolumn{2}{|c|}{9,798} \\
\hline
\end{tabular}

Source: CUNY administrative data. Notes: Sample includes first-time CUNY noncitizen undergraduate degree-seeking senior college students from New York belonging to the Fall 1999 through Fall 2001 or Fall 2002 through Fall 2005 entering cohorts. Each cell displays the coefficient on the interaction between undocumented status and belong to a cohort that entered between Spring 2002. All models include controls for undocumented status, entry cohort, and cohort linear time trends, allowed to vary by documentation status. Clustered standard errors (institution by cohort) in parentheses. 
Table 11: Impacts of the Tuition Increase on Cumulative Credits Earned and Degree Receipt: Senior College Students

\begin{tabular}{|c|c|c|c|c|}
\hline \multirow{3}{*}{ A. All senior college students } & \multirow{2}{*}{$\begin{array}{l}\text { 1. Cumulative } \\
\text { credits earned }\end{array}$} & \multicolumn{3}{|c|}{ Degree Receipt: } \\
\hline & & 2. Any degree & 3. AA/AS & 4. BA/BS \\
\hline & & & & \\
\hline Undocumented × 2000 entrant & $\begin{array}{l}-2.37 \\
(3.69)\end{array}$ & $\begin{array}{l}-0.030 \\
(0.047)\end{array}$ & $\begin{array}{l}-0.001 \\
(0.026)\end{array}$ & $\begin{array}{l}-0.020 \\
(0.041)\end{array}$ \\
\hline Undocumented × 2001 entrant & $\begin{array}{c}-7.01 \\
(3.08)^{*}\end{array}$ & $\begin{array}{c}-0.104 \\
(0.047)^{*}\end{array}$ & $\begin{array}{l}-0.042 \\
(0.028)\end{array}$ & $\begin{array}{c}-0.086 \\
(0.043)+\end{array}$ \\
\hline Undocumented mean (1999) & 73.9 & 0.48 & 0.13 & 0.40 \\
\hline Impact in \% change: 2000 cohort & $-3 \%$ & $-6 \%$ & $-1 \%$ & $-5 \%$ \\
\hline Impact in \% change: 2001 cohort & $-9 \%$ & $-22 \%$ & $-32 \%$ & $-22 \%$ \\
\hline Observations & 9,798 & 9,798 & 9,798 & 9,798 \\
\hline \multicolumn{5}{|l|}{ B. Bachelor's degree-seeking } \\
\hline Undocumented × 2000 entrant & $\begin{array}{l}-5.07 \\
(4.78)\end{array}$ & $\begin{array}{l}-0.017 \\
(0.062)\end{array}$ & $\begin{array}{c}0.011 \\
(0.018)\end{array}$ & $\begin{array}{l}-0.026 \\
(0.063)\end{array}$ \\
\hline Undocumented × 2001 entrant & $\begin{array}{c}-8.28 \\
(4.47)^{+}\end{array}$ & $\begin{array}{l}-0.099 \\
(0.064)\end{array}$ & $\begin{array}{c}0.009 \\
(0.016)\end{array}$ & $\begin{array}{c}-0.119 \\
(0.064)+\end{array}$ \\
\hline Undocumented mean (1999) & 84.4 & 0.55 & 0.04 & 0.52 \\
\hline Impact in \% change: 2000 cohort & $-6 \%$ & $-3 \%$ & $28 \%$ & $-5 \%$ \\
\hline Impact in \% change: 2001 cohort & $-10 \%$ & $-18 \%$ & $23 \%$ & $-23 \%$ \\
\hline Observations & 6,190 & 6,190 & 6,190 & 6,190 \\
\hline \multicolumn{5}{|l|}{ C. Associate's degree-seeking } \\
\hline Undocumented $\times 2000$ entrant & $\begin{array}{c}2.24 \\
(4.67)\end{array}$ & $\begin{array}{l}-0.045 \\
(0.052)\end{array}$ & $\begin{array}{l}-0.003 \\
(0.044)\end{array}$ & $\begin{array}{l}-0.018 \\
(0.040)\end{array}$ \\
\hline Undocumented × 2001 entrant & $\begin{array}{l}-5.78 \\
(3.69)\end{array}$ & $\begin{array}{c}-0.109 \\
(0.050)^{*}\end{array}$ & $\begin{array}{c}-0.119 \\
(0.044)^{*}\end{array}$ & $\begin{array}{l}-0.038 \\
(0.030)\end{array}$ \\
\hline Undocumented mean (1999) & 58.8 & 0.39 & 0.26 & 0.22 \\
\hline Impact in \% change: 2000 cohort & $4 \%$ & $-12 \%$ & $-1 \%$ & $-8 \%$ \\
\hline Impact in \% change: 2001 cohort & $-10 \%$ & $-28 \%$ & $-46 \%$ & $-17 \%$ \\
\hline Observations & 3,608 & 3,608 & 3,608 & 3,608 \\
\hline
\end{tabular}

Source: CUNY administrative data. Notes: Sample includes first-time CUNY noncitizen undergraduate degree-seeking senior college students who earned a high school diploma or GED from New York State and belonged to the Fall 1999 through Fall 2001 entering cohorts. Each column within a panel represents a separate regression. Clustered standard errors (institution by cohort) in parentheses; ${ }^{* *} \mathrm{p}<0.01,{ }^{*} \mathrm{p}<0.05,+\mathrm{p}<0.1$. Reported coefficients are interactions between an indicator for whether a student is an undocumented noncitizen and belonging to either the 2000 or 2001 entry cohort. See Table 2 notes for description of additional control variables. 
Appendix A Additional Figures and Tables 
Table A.1: Characteristics of Students by Citizenship and Documentation Status at Entry: Senior College Students

\begin{tabular}{|c|c|c|c|c|c|c|}
\hline & \multirow[b]{2}{*}{ (1) Citizens } & \multicolumn{2}{|c|}{ Noncitizens } & \multicolumn{3}{|c|}{ Tests of equality ( $p$-value) } \\
\hline & & (2) Documented & (3) Undocumented & $\begin{array}{c}\text { Citizen vs. } \\
\text { noncitizens }\end{array}$ & $\begin{array}{c}\text { Documented } \\
\text { vs. undoc. }\end{array}$ & $\begin{array}{c}\text { All three } \\
\text { groups }\end{array}$ \\
\hline Age & 19 & 19 & 19 & 0.01 & 0.835 & 0.035 \\
\hline Female & 0.58 & 0.57 & 0.58 & 0.509 & 0.619 & 0.711 \\
\hline \multicolumn{7}{|l|}{ Race/ethnicity: } \\
\hline Asian/Pacific Islander & 0.10 & 0.30 & 0.26 & $<0.001$ & 0.004 & $<0.001$ \\
\hline Black & 0.28 & 0.26 & 0.33 & 0.007 & $<0.001$ & $<0.001$ \\
\hline Hispanic & 0.29 & 0.21 & 0.25 & $<0.001$ & 0.002 & $<0.001$ \\
\hline White & 0.33 & 0.23 & 0.16 & $<0.001$ & $<0.001$ & $<0.001$ \\
\hline Single parent & 0.02 & 0.01 & 0.01 & 0.128 & 0.633 & 0.283 \\
\hline Disabled & 0.03 & 0.01 & 0.02 & $<0.001$ & 0.293 & $<0.001$ \\
\hline Foreign-born & 0.08 & 1 & 1 & & & \\
\hline Permanent resident & -- & 0.94 & -- & & & \\
\hline Visa-holder & -- & 0.06 & -- & & & \\
\hline Refugee & -- & 0 & -- & & & \\
\hline Need any remediation & 0.33 & 0.42 & 0.38 & $<0.001$ & 0.039 & $<0.001$ \\
\hline \multicolumn{7}{|l|}{ High school type: } \\
\hline NYC public & 0.69 & 0.86 & 0.85 & $<0.001$ & 0.179 & $<0.001$ \\
\hline NYC private & 0.18 & 0.05 & 0.04 & $<0.001$ & 0.446 & $<0.001$ \\
\hline GED & 0.06 & 0.07 & 0.06 & $<0.001$ & 0.741 & $<0.001$ \\
\hline High school GPA (0-100) & 78 & 80 & 80 & $<0.001$ & 0.488 & $<0.001$ \\
\hline Missing high school GPA & 0.02 & 0.02 & 0.02 & $<0.001$ & 0.663 & $<0.001$ \\
\hline Bachelor's degree program & 0.61 & 0.63 & 0.62 & 0.002 & 0.395 & 0.005 \\
\hline \multicolumn{7}{|l|}{ Initial institution selectivity: } \\
\hline Very competitive & 0.09 & 0.13 & 0.1 & $<0.001$ & 0.038 & $<0.001$ \\
\hline Competitive & 0.48 & 0.45 & 0.47 & $<0.001$ & 0.208 & $<0.001$ \\
\hline Less/noncompetitive & 0.43 & 0.42 & 0.42 & 0.119 & 0.835 & 0.291 \\
\hline Observations & 25,999 & 8,919 & 876 & & & \\
\hline
\end{tabular}

Source: CUNY administrative data. Notes: Sample includes first-time CUNY undergraduate degree-seeking students belonging to the Fall 1999 through Fall 2002 entering cohorts who initially enrolled in a senior college. See Table 1 notes for additional details. 
Table A.2: Characteristics of Students by Citizenship and Documentation Status at Entry: Community College Students

\begin{tabular}{|c|c|c|c|c|c|c|}
\hline & \multirow[b]{2}{*}{ (1) Citizens } & \multicolumn{2}{|c|}{$\underline{\text { Noncitizens }}$} & \multicolumn{3}{|c|}{ Tests of equality ( $p$-value) } \\
\hline & & (2) Documented & (3) Undocumented & $\begin{array}{c}\text { Citizen vs. } \\
\text { noncitizens }\end{array}$ & $\begin{array}{c}\text { Documented } \\
\text { vs. undoc. }\end{array}$ & $\begin{array}{c}\text { All three } \\
\text { groups }\end{array}$ \\
\hline Age & 21 & 21 & 21 & $<0.001$ & 0.377 & $<0.001$ \\
\hline Female & 0.59 & 0.60 & 0.60 & 0.107 & 0.931 & 0.273 \\
\hline \multicolumn{7}{|l|}{ Race/ethnicity: } \\
\hline Asian/Pacific Islander & 0.06 & 0.19 & 0.20 & $<0.001$ & 0.270 & $<0.001$ \\
\hline Black & 0.33 & 0.31 & 0.35 & $<0.001$ & 0.012 & $<0.001$ \\
\hline Hispanic & 0.38 & 0.38 & 0.31 & 0.036 & $<0.001$ & $<0.001$ \\
\hline White & 0.22 & 0.13 & 0.14 & $<0.001$ & 0.353 & $<0.001$ \\
\hline Single parent & 0.04 & 0.04 & 0.03 & 0.065 & 0.053 & 0.032 \\
\hline Disabled & 0.04 & 0.02 & 0.03 & $<0.001$ & 0.480 & $<0.001$ \\
\hline Foreign-born & 0.09 & 1 & 1 & & & \\
\hline Permanent resident & -- & 0.93 & -- & -- & -- & -- \\
\hline Visa-holder & -- & 0.07 & -- & -- & -- & -- \\
\hline Refugee & -- & $<0.01$ & -- & -- & -- & -- \\
\hline \multicolumn{6}{|l|}{ High school type: } & $<0.001$ \\
\hline NYC public & 0.60 & 0.66 & 0.65 & $<0.001$ & 0.477 & $<0.001$ \\
\hline NYC private & 0.10 & 0.02 & 0.02 & $<0.001$ & 0.287 & $<0.001$ \\
\hline GED & 0.28 & 0.30 & 0.30 & $<0.001$ & 0.772 & $<0.001$ \\
\hline High school GPA (0-100) & 72 & 74 & 75 & $<0.001$ & $<0.001$ & $<0.001$ \\
\hline Missing high school GPA & 0.08 & 0.06 & 0.09 & 0.005 & 0.011 & 0.001 \\
\hline Observations & 17,160 & 7,188 & 932 & & & \\
\hline
\end{tabular}

Source: CUNY administrative data. Notes: Sample includes first-time CUNY undergraduate degree-seeking students belonging to the Fall 1999 through Fall 2002 entering cohorts who initially enrolled in a community college. See Table 1 notes for additional details. 
Table A.3: Heterogeneity in the Impact of the Tuition Increase on Attainment by Initial Degree Program: Senior College Students

\begin{tabular}{|c|c|c|c|}
\hline & $\begin{array}{l}\text { (1) Bachelor's } \\
\text { degree-seeking }\end{array}$ & $\begin{array}{l}\text { (2) Associate's } \\
\text { degree-seeking }\end{array}$ & $\begin{array}{l}\text { Test of eq. } \\
\text { ( } p \text {-value })\end{array}$ \\
\hline \multicolumn{4}{|l|}{ A. Reenrollment } \\
\hline Undocumented ${ }^{x}$ spring 2002 & $\begin{array}{c}-0.071 \\
(0.014)^{* *}\end{array}$ & $\begin{array}{c}-0.054 \\
(0.020)^{*}\end{array}$ & 0.455 \\
\hline Undocumented x post-spring 2002 & $\begin{array}{c}-0.042 \\
(0.015)^{* *}\end{array}$ & $\begin{array}{c}0.001 \\
(0.022)\end{array}$ & 0.087 \\
\hline Test of equality ( $p$-value) & 0.007 & 0.070 & \\
\hline Fall 2001 undocumented mean & 0.88 & 0.77 & \\
\hline $\begin{array}{l}\text { Impact in \% change: spring } 2002 \\
\text { Impact in \% change: post-spring } 2002\end{array}$ & $\begin{array}{l}-8 \% \\
-5 \%\end{array}$ & $\begin{array}{l}-7 \% \\
0.1 \%\end{array}$ & \\
\hline Observations & 38,674 & 22,807 & \\
\hline \multicolumn{4}{|l|}{ B. Credits attempted } \\
\hline Undocumented x spring 2002 & $\begin{array}{c}-0.912 \\
(0.226)^{* *}\end{array}$ & $\begin{array}{c}-0.914 \\
(0.299)^{* *}\end{array}$ & 0.995 \\
\hline Undocumented ${ }^{x}$ post-spring 2002 & $\begin{array}{c}-0.494 \\
(0.213)^{*}\end{array}$ & $\begin{array}{c}-0.637 \\
(0.346)+\end{array}$ & 0.724 \\
\hline Test of equality ( $p$-value) & 0.048 & 0.273 & \\
\hline Fall 2001 undocumented mean & 10.5 & 7.5 & \\
\hline $\begin{array}{l}\text { Impact in \% change: spring } 2002 \\
\text { Impact in \% change: post-spring } 2002\end{array}$ & $\begin{array}{l}-9 \% \\
-5 \%\end{array}$ & $\begin{array}{l}-12 \% \\
-8 \%\end{array}$ & \\
\hline Observations & 38,674 & 22,807 & \\
\hline \multicolumn{4}{|l|}{ B. Credits earned } \\
\hline Undocumented ${ }^{x}$ spring 2002 & $\begin{array}{c}-0.862 \\
(0.228)^{* *}\end{array}$ & $\begin{array}{l}-0.603 \\
(0.221)^{*}\end{array}$ & 0.414 \\
\hline Undocumented x post-spring 2002 & $\begin{array}{c}-0.469 \\
(0.180)^{*}\end{array}$ & $\begin{array}{c}-0.586 \\
(0.297)+\end{array}$ & 0.731 \\
\hline Test of equality ( $p$-value) & 0.077 & 0.950 & \\
\hline Fall 2001 undocumented mean & 9.6 & 6.6 & \\
\hline Impact in \% change: spring 2002 & $-9 \%$ & $-9 \%$ & \\
\hline Impact in \% change: post-spring 2002 & $-5 \%$ & $-9 \%$ & \\
\hline Observations & 38,674 & 22,807 & \\
\hline
\end{tabular}

Source: CUNY administrative data. Notes: Sample includes first-time CUNY noncitizen undergraduate degree-seeking students from New York belonging to the Fall 1999 through Fall 2002 entering cohorts who initially enrolled in Baruch, Brooklyn, City, Hunter, John Jay, Queens, Lehman, City College of Technology, Staten Island, or York Colleges. Each column within a panel represents a separate regression. Clustered standard errors (institution by cohort) in parentheses; ${ }^{* *} \mathrm{p}<0.01,{ }^{*} \mathrm{p}<0.05,+$ $\mathrm{p}<0.1$. Reported coefficients are interactions between an indicator for whether a student is an undocumented noncitizen at college entry and Spring 2002 and undocumented status with post-Spring 2002. See Table 2 notes for additional details. 
Table A.4: Robustness of Estimated Impacts on Attainment to Excluding BMCC

\begin{tabular}{lc}
\hline & $\begin{array}{c}\text { (1) Community } \\
\text { college students }\end{array}$ \\
\hline A. Reenrollment & \\
Undocumented x spring 2002 & -0.008 \\
& $(0.022)$ \\
Undocumented x post-spring 2002 & 0.0003 \\
& $(0.017)$ \\
Test of equality (p- value) & 0.512 \\
Fall 2001 undocumented mean & 0.73 \\
Impact in \% change: spring 2002 & $-1 \%$ \\
Impact in \% change: post-spring 2002 & $0.04 \%$ \\
Observations & 35,723 \\
\hline B. Credits earned & \\
Undocumented x spring 2002 & -0.478 \\
& $(0.169)^{* *}$ \\
Undocumented x post-spring 2002 & -0.392 \\
& $(0.191)^{+}$ \\
Test of equality (p- value) & 0.644 \\
Fall 2001 undocumented mean & 5.8 \\
Impact in \% change: spring 2002 & $-8 \%$ \\
Impact in \% change: post-spring 2002 & $-7 \%$ \\
Observations & 35,723 \\
\hline
\end{tabular}

Source: CUNY administrative data. Notes: Sample includes first-time CUNY noncitizen undergraduate degree-seeking students who earned a high school diploma or GED from New York State belonging to the Fall 1999 through Fall 2002 entering cohorts, excluding BMCC students. Each column within a panel represents a separate regression. Clustered standard errors (institution by cohort) in parentheses; ${ }^{* *} \mathrm{p}<0.01,{ }^{*} \mathrm{p}<0.05,+\mathrm{p}<0.1$. See Table 2 notes for additional details. 
Table A.5: Robustness of Estimated Impacts on Attainment of Enrolled Students to Excluding BMCC

(1) Community college students

\begin{tabular}{|c|c|}
\hline \multirow{2}{*}{\multicolumn{2}{|c|}{ A. $\operatorname{Pr}\left(\right.$ enrolled $\left._{t}\right) \mid$ enrolled $_{t-1}$}} \\
\hline & \\
\hline Undocumented x spring 2002 & $\begin{array}{c}0.001 \\
(0.031)\end{array}$ \\
\hline Undocumented ${ }^{x}$ post-spring 2002 & $\begin{array}{c}0.029 \\
(0.016)^{+}\end{array}$ \\
\hline Test of equality ( $p$-value) & 0.283 \\
\hline Fall 2001 undocumented mean & 0.77 \\
\hline Impact in \% change: spring 2002 & $0.1 \%$ \\
\hline Impact in \% change: post-spring 2002 & $4 \%$ \\
\hline Observations & 19,948 \\
\hline \multicolumn{2}{|l|}{ B. Credits earned $\mid$ enrolled } \\
\hline Undocumented × Spring 2002 or later & $\begin{array}{c}-0.595 \\
(0.241)^{*}\end{array}$ \\
\hline Undocumented × Post-Spring 2002 & $\begin{array}{c}-0.643 \\
(0.239)^{*}\end{array}$ \\
\hline Test of equality ( $p$-value) & 0.858 \\
\hline Fall 2001 undocumented mean & 8.3 \\
\hline Impact in \% Change - Spring 2002 & $-7 \%$ \\
\hline Impact in \% Change - Post-Spring 2002 & $-8 \%$ \\
\hline Observations & 21,745 \\
\hline \multicolumn{2}{|l|}{ C. GPA $\mid$ enrolled } \\
\hline Undocumented × Spring 2002 & $\begin{array}{l}-0.013 \\
(0.057)\end{array}$ \\
\hline Undocumented × Post-Spring 2002 & $\begin{array}{l}-0.003 \\
(0.039)\end{array}$ \\
\hline Test of equality ( $p$-value) & 0.848 \\
\hline Fall 2001 undocumented mean & 2.33 \\
\hline Impact in \% Change - Spring 2002 & $-1 \%$ \\
\hline Impact in \% Change - Post-Spring 2002 & $-0.1 \%$ \\
\hline Observations & 21,737 \\
\hline
\end{tabular}

Source: CUNY administrative data. Notes: Sample includes first-time CUNY noncitizen undergraduate degree-seeking students who earned a high school diploma or GED from New York State belonging to the Fall 1999 through Fall 2002 entering cohorts, excluding BMCC students. Each column within a panel represents a separate regression. Clustered standard errors (institution by cohort) in parentheses; ${ }^{*} \mathrm{p}<0.01,{ }^{*} \mathrm{p}<0.05,+\mathrm{p}<0.1$. See Table 5 notes for additional details. 
Table A.6: Heterogeneity in the Impact of the Tuition Increase on Attainment of Enrolled Students by Initial Degree Program: Senior College Students

\begin{tabular}{|c|c|c|c|}
\hline & $\begin{array}{l}\text { (1) Bachelor's } \\
\text { degree-seeking }\end{array}$ & $\begin{array}{l}\text { (2) Associate's } \\
\text { degree-seeking }\end{array}$ & $\begin{array}{l}\text { Test of eq. } \\
\text { ( } p \text {-value) }\end{array}$ \\
\hline \multicolumn{4}{|l|}{ A. $\operatorname{Pr}\left(\right.$ enrolled $\left._{t}\right) \mid$ enrolled $_{t-1}$} \\
\hline Undocumented x spring 2002 & $\begin{array}{c}-0.067 \\
(0.015)^{* *}\end{array}$ & $\begin{array}{c}-0.061 \\
(0.027)^{*}\end{array}$ & 0.836 \\
\hline Undocumented x post-spring 2002 & $\begin{array}{l}-0.013 \\
(0.011)\end{array}$ & $\begin{array}{c}0.010 \\
(0.022)\end{array}$ & 0.341 \\
\hline Test of equality ( $p$-value) & 0.002 & 0.02 & \\
\hline Fall 2001 undocumented mean & 0.92 & 0.88 & \\
\hline Impact in \% Change - Spring 2002 & $-7 \%$ & $-7 \%$ & \\
\hline Impact in \% Change - Post-Spring 2002 & $-1 \%$ & $1 \%$ & \\
\hline Observations & 32,165 & 15,582 & \\
\hline \multicolumn{4}{|l|}{ B. Credits earned | enrolled } \\
\hline Undocumented x spring 2002 & $\begin{array}{l}-0.148 \\
(0.234)\end{array}$ & $\begin{array}{l}-0.284 \\
(0.226)\end{array}$ & 0.689 \\
\hline Undocumented x post-spring 2002 & $\begin{array}{l}-0.093 \\
(0.153)\end{array}$ & $\begin{array}{c}-0.916 \\
(0.352)^{*}\end{array}$ & 0.029 \\
\hline Test of equality ( $p$ - value) & 0.834 & 0.022 & \\
\hline Fall 2001 undocumented mean & 11 & 8.8 & \\
\hline Impact in \% Change - Spring 2002 & $-1 \%$ & $-3 \%$ & \\
\hline Impact in \% Change - Post-Spring 2002 & $-1 \%$ & $-10 \%$ & \\
\hline Observations & 31,275 & 14,591 & \\
\hline \multicolumn{4}{|l|}{ C. GPA | enrolled } \\
\hline Undocumented ${ }^{x}$ spring 2002 & $\begin{array}{l}-0.064 \\
(0.059)\end{array}$ & $\begin{array}{c}0.014 \\
(0.054)\end{array}$ & 0.317 \\
\hline Undocumented x post-spring 2002 & $\begin{array}{l}-0.039 \\
(0.042)\end{array}$ & $\begin{array}{c}0.012 \\
(0.038)\end{array}$ & 0.369 \\
\hline Test of equality ( $p$-value) & 0.547 & 0.959 & \\
\hline Fall 2001 undocumented mean & 2.68 & 2.36 & \\
\hline Impact in \% Change - Spring 2002 & $-2 \%$ & $1 \%$ & \\
\hline Impact in \% Change - Post-Spring 2002 & $-1 \%$ & $1 \%$ & \\
\hline Observations & 31,242 & 14,575 & \\
\hline
\end{tabular}

Source: CUNY administrative data. Notes: Sample includes first-time CUNY noncitizen undergraduate degree-seeking students who earned a high school diploma or GED from New York State belonging to the Fall 1999 through Fall 2002 entering cohorts who initially enrolled in Baruch, Brooklyn, City, Hunter, John Jay, Queens, Lehman, City College of Technology, Staten Island, or York Colleges. Each column within a panel represents a separate regression. Clustered standard errors (institution by cohort) in parentheses; ${ }^{* *} \mathrm{p}<0.01,{ }^{*} \mathrm{p}<0.05,+\mathrm{p}<0.1$. See Table 2 notes for additional control variables. Student by semester observations are dropped following degree receipt. Panel A sample conditions on enrollment in semester $t-1$. Panels B and $\mathrm{C}$ samples condition on enrollment in semester $t$. 
Table A.7: The Impact of the Tuition Increase on the Attainment of Enrolled Undocumented Students: Student Fixed-Effects Models

\begin{tabular}{lcc}
\hline & $\begin{array}{c}\text { (1) Senior college } \\
\text { students }\end{array}$ & $\begin{array}{c}\text { (2) Community } \\
\text { college students }\end{array}$ \\
\hline A. Credits earned | enrolled & & \\
Undocumented × Spring 2002 or later & -0.223 & -0.647 \\
& $(0.178)$ & $(0.149)^{* *}$ \\
Undocumented × Post-Spring 2002 & -0.295 & -0.630 \\
& $(0.194)$ & $(0.230)^{*}$ \\
Test of equality (p- value) & 0.747 & 0.936 \\
Fall 2001 undocumented mean & 10.3 & 8.1 \\
Impact in \% Change - Spring 2002 & $-2 \%$ & $-8 \%$ \\
Impact in \% Change - Post-Spring 2002 & $-3 \%$ & $-8 \%$ \\
Observations & 45,866 & 31,155 \\
\hline B. GPA | enrolled & & \\
Undocumented × Spring 2002 & -0.018 & 0.035 \\
& $(0.041)$ & $(0.038)$ \\
Undocumented × Post-Spring 2002 & 0.010 & 0.005 \\
& $(0.034)$ & $(0.043)$ \\
Test of equality (p- value) & 0.347 & 0.629 \\
Fall 2001 undocumented mean & 2.57 & 2.40 \\
Impact in \% Change - Spring 2002 & $-1 \%$ & $1 \%$ \\
Impact in \% Change - Post-Spring 2002 & $0.4 \%$ & $0.2 \%$ \\
Observations & 45,817 & 31,141 \\
\hline
\end{tabular}

Source: CUNY administrative data. Notes: Sample includes first-time CUNY noncitizen undergraduate degree-seeking students who earned a high school diploma or GED from New York State belonging to the Fall 1999 through Fall 2002 entering cohorts and were enrolled in semester $t$. Each column within a panel represents a separate regression. Clustered standard errors (institution by cohort) in parentheses; ${ }^{* *} \mathrm{p}<0.01,{ }^{*} \mathrm{p}<0.05,+\mathrm{p}<0.1$. See Table 2 notes for additional control variables and definitions of senior and community college samples. All regressions include student fixed-effects. Student by semester observations are dropped following degree receipt. 
Table A.8: Selection into Exit in Spring 2002: Senior College Students

\begin{tabular}{lcc}
\hline & $\begin{array}{c}\text { (1) Cumulative } \\
\text { GPA }\end{array}$ & $\begin{array}{c}\text { (2) Cumulative } \\
\text { credits earned }\end{array}$ \\
\cline { 2 - 3 } Undocumented x spring 2002 & 0.208 & 2.493 \\
& $(0.145)$ & $(1.180)^{*}$ \\
Fall 2001 undocumented mean & 1.99 & 18 \\
Impact in \% change: spring 2002 & $10 \%$ & $14 \%$ \\
Observations & 4,291 & 4,291 \\
\hline
\end{tabular}

Source: CUNY administrative data. Notes: Sample includes first-time CUNY noncitizen undergraduate degree-seeking senior college students who earned a high school diploma or GED from New York State belonging to the Fall 1999 through Fall 2002 entering cohorts and exited from college in semester $t$. Dependent variable is cumulative GPA or cumulative credits earned at the time of exit. Each column represents a separate regression. Clustered standard errors (institution by cohort) in parentheses; ** $\mathrm{p}<0.01,{ }^{*} \mathrm{p}<0.05,+\mathrm{p}<0.1$. See Table 2 notes for additional control variables. Student by semester observations are dropped following degree receipt. 
Table A.9: Heterogeneity in the Impact of the Tuition Increase by Race/Ethnicity

\begin{tabular}{|c|c|c|c|c|c|c|c|c|}
\hline & \multicolumn{4}{|c|}{$\underline{\text { Senior college students }}$} & \multicolumn{4}{|c|}{ Community College Students } \\
\hline & 1. Asian & 2. Black & 3. Hisp. & 4. White & 5. Asian & 6. Black & 7. Hisp. & 8. White \\
\hline \multicolumn{9}{|l|}{ A. Reenrollment } \\
\hline \multirow[t]{3}{*}{ Undocumented $\times$ spring 2002} & -0.064 & -0.055 & -0.083 & -0.037 & 0.015 & 0.007 & -0.031 & -0.063 \\
\hline & $(0.021)^{* *}$ & $(0.023)^{*}$ & $(0.024)^{* *}$ & $(0.032)$ & $(0.027)$ & $(0.022)$ & $(0.028)$ & $(0.026)^{*}$ \\
\hline & \multicolumn{4}{|c|}{ [0.757] } & \multicolumn{4}{|c|}{$[0.066]$} \\
\hline \multirow[t]{3}{*}{ Undocumented × post-spring 2002} & -0.005 & -0.026 & 0.002 & -0.057 & -0.005 & 0.017 & -0.019 & -0.031 \\
\hline & $(0.020)$ & $(0.023)$ & $(0.031)$ & $(0.029)+$ & $(0.029)$ & $(0.023)$ & $(0.028)$ & $(0.032)$ \\
\hline & \multicolumn{4}{|c|}{ [0.438] } & \multicolumn{4}{|c|}{ [0.647] } \\
\hline Fall 2001 undocumented mean & 0.88 & 0.77 & 0.83 & 0.91 & 0.76 & 0.73 & 0.71 & 0.72 \\
\hline Observations & 18,194 & 16,605 & 13,189 & 13,455 & 9,590 & 15,795 & 19,049 & 6,550 \\
\hline \multicolumn{9}{|l|}{ B. Credits earned } \\
\hline \multirow[t]{3}{*}{ Undocumented x spring 2002} & -0.407 & -0.604 & -1.384 & -0.439 & -0.218 & -0.307 & -0.596 & -0.460 \\
\hline & $(0.306)$ & $(0.284)^{*}$ & $(0.318)^{* *}$ & $(0.392)$ & $(0.308)$ & $(0.204)$ & $(0.324)+$ & $(0.509)$ \\
\hline & \multicolumn{4}{|c|}{$[0.102]$} & \multicolumn{4}{|c|}{$[0.855]$} \\
\hline \multirow[t]{3}{*}{ Undocumented x post-spring 2002} & -0.650 & -0.238 & -0.583 & -0.418 & 0.096 & -0.091 & -0.952 & 0.048 \\
\hline & $(0.302)^{*}$ & $(0.305)$ & $(0.346)+$ & $(0.357)$ & $(0.337)$ & $(0.286)$ & $(0.274)^{* *}$ & $(0.387)$ \\
\hline & \multicolumn{4}{|c|}{$[0.837]$} & \multicolumn{4}{|c|}{$[0.134]$} \\
\hline Fall 2001 undocumented mean & 9.3 & 7.6 & 8.1 & 9.6 & 5.8 & 5.9 & 5.1 & 6.3 \\
\hline Observations & 18,194 & 16,605 & 13,189 & 13,455 & 9,590 & 15,795 & 19,049 & 6,550 \\
\hline
\end{tabular}

Source: CUNY administrative data. Notes: Sample includes first-time CUNY noncitizen undergraduate degree-seeking students who earned a high school diploma or GED from New York State belonging to the Fall 1999 through Fall 2002 entering cohorts. Students classified as Native American are excluded due to their small group size. Each column within a panel represents a separate regression. Clustered standard errors (institution by cohort) in parentheses; ${ }^{* *} \mathrm{p}<0.01,{ }^{*} \mathrm{p}<0.05,+\mathrm{p}<0.1$. Brackets contain $p$-values from test of equality of treatment variables by race/ethnicity. See Table 2 notes for description of control variables and specification. 
Table A.10: Changes in Observed Characteristics between Affected and Unaffected Undocumented Entry Cohorts: Community College Students

\begin{tabular}{lcc}
\hline & $\begin{array}{c}\text { Undocumented }{ }^{x} \\
\text { 2000 entrant }\end{array}$ & $\begin{array}{c}\text { Undocumented } \\
\text { 2001 entrant }\end{array}$ \\
\hline Dependent var: & & \\
Age & -0.345 & -0.085 \\
& $(0.347)$ & $(0.420)$ \\
Female & 0.021 & -0.027 \\
& $(0.043)$ & $(0.042)$ \\
Black & -0.002 & 0.028 \\
& $(0.052)$ & $(0.052)$ \\
Hispanic & 0.033 & 0.008 \\
& $(0.063)$ & $(0.068)$ \\
White & -0.042 & -0.071 \\
& $(0.021)^{+}$ & $(0.030)^{*}$ \\
Single Parent & -0.022 & -0.034 \\
Needs remediation & $(0.013)+$ & $(0.013)^{*}$ \\
Disabled & 0.006 & 0.002 \\
High school GPA & $(0.029)$ & $(0.036)$ \\
Test of joint sig. ( $p$ - val.) & -0.017 & -0.022 \\
Observations & $(0.014)$ & $(0.013)^{+}$ \\
Missing hs GPA & -2.154 & -3.032 \\
NYC public high school & $(2.190)$ & $(1.783)^{+}$ \\
GED & 0.020 & 0.035 \\
& $(0.030)$ & $(0.024)$ \\
& -0.017 & 0.005 \\
& $(0.045)$ & $(0.047)$ \\
& -0.006 & 0.009 \\
& $(0.042)$ & $(0.045)$ \\
& $<0.001$ & $<0.001$ \\
& & 8,120 \\
\hline
\end{tabular}

Source: CUNY administrative data. Notes: Sample includes first-time CUNY noncitizen undergraduate degree-seeking community college students from New York belonging to the Fall 1999 through Fall 2001 or Fall 2002 through Fall 2005 entering cohorts. Each cell displays the coefficient on the interaction between undocumented status and belong to a cohort that entered between Spring 2002. All models include controls for undocumented status, entry cohort, and cohort linear time trends, allowed to vary by documentation status. Clustered standard errors (institution by cohort) in parentheses. 
Table A.11: Impacts of the Tuition Increase on Cumulative Credits Earned and Degree Receipt: Community College Students

\begin{tabular}{lcccc}
\hline & $\begin{array}{c}\text { 1. Cumulative } \\
\text { credits earned }\end{array}$ & 2. Any degree & 3. AA/AS & 4. BA/BS \\
\cline { 2 - 5 } & -1.86 & -0.041 & -0.018 & -0.016 \\
Undocumented × 2000 entrant & $(2.65)$ & $(0.031)$ & $(0.025)$ & $(0.026)$ \\
& -0.30 & 0.0001 & 0.018 & -0.029 \\
Undocumented × 2001 entrant & $(2.64)$ & $(0.031)$ & $(0.027)$ & $(0.027)$ \\
& 50.0 & 0.37 & 0.33 & 0.12 \\
Undocumented mean (1999) & $-4 \%$ & $-11 \%$ & $-5 \%$ & $-13 \%$ \\
Impact in \% change: 2000 cohort & $-1 \%$ & $0.03 \%$ & $5 \%$ & $-24 \%$ \\
Impact in \% change: 2001 cohort & 8,120 & 8,120 & 8,120 & 8,120 \\
\hline Observations & & & &
\end{tabular}

Source: CUNY administrative data. Notes: Sample includes first-time CUNY noncitizen undergraduate degree-seeking community college students who earned a high school diploma or GED from New York State and belonged to the Fall 1999 through Fall 2001 entering cohorts. Each column within a panel represents a separate regression. Clustered standard errors (institution by cohort) in parentheses; ${ }^{* *} \mathrm{p}<0.01,{ }^{*} \mathrm{p}<0.05,+\mathrm{p}<0.1$. Reported coefficients are interactions between an indicator for whether a student is an undocumented noncitizen and belonging to either the 2000 or 2001 entry cohort. See Table 2 notes for description of additional control variables. 